\title{
Tomato Landraces Are Competitive with Commercial Varieties in Terms of Tolerance to Plant Pathogens-A Case Study of Hungarian Gene Bank Accessions on Organic Farms
}

\author{
Krisztina Boziné-Pullai ${ }^{1}$, László Csambalik ${ }^{2}{ }^{\mathbb{D}}$, Dóra Drexler ${ }^{3}$, Dániel Reiter ${ }^{2}$, Ferenc Tóth ${ }^{4}{ }^{\mathbb{D}}$, \\ Franciska Tóthné Bogdányi ${ }^{5}$ and Márta Ladányi ${ }^{6, *}$
}

Citation: Boziné-Pullai, K.; Csambalik, L.; Drexler, D.; Reiter, D.; Tóth, F.; Tóthné Bogdányi, F.; Ladányi, M. Tomato Landraces Are Competitive with Commercial Varieties in Terms of Tolerance to Plant Pathogens-A Case Study of Hungarian Gene Bank Accessions on Organic Farms. Diversity 2021, 13, 195. https://doi.org/10.3390/d13050195

Academic Editor: Michael Wink

Received: 3 April 2021

Accepted: 27 April 2021

Published: 30 April 2021

Publisher's Note: MDPI stays neutral with regard to jurisdictional claims in published maps and institutional affiliations.

Copyright: (c) 2021 by the authors. Licensee MDPI, Basel, Switzerland. This article is an open access article distributed under the terms and conditions of the Creative Commons Attribution (CC BY) license (https:// creativecommons.org/licenses/by/ $4.0 /)$.
1 Doctoral School of Plant Sciences, Hungarian University of Agriculture and Life Sciences, H-2103 Gödöllő, Hungary; bozine.pullai.krisztina@phd.uni-mate.hu

2 Department of Agroecology and Organic Farming, Institute of Sustainable Development and Production, Hungarian University of Agriculture and Life Sciences, H-1118 Budapest, Hungary; csambalik.laszlo.orban@uni-mate.hu (L.C.); danielreiter87@gmail.com (D.R.)

3 Hungarian Research Institute of Organic Agriculture (ÖMKi), H-1033 Budapest, Hungary; dora.drexler@biokutatas.hu

4 Department of Zoology and Ecology, Institute for Wildlife Management and Nature Conservation, Hungarian University of Agriculture and Life Sciences, H-2103 Gödöllő, Hungary; toth.ferenc.vti@uni-mate.hu

5 ImMuniPot Research Group, H-2100 Gödöllő, Hungary; t.bogdanyi.franciska@gmail.com

6 Department of Applied Statistics, Institute of Mathematics and Basic Science, Hungarian University of Agriculture and Life Sciences, H-1118 Budapest, Hungary

* Correspondence: ladanyi.marta@uni-mate.hu

\begin{abstract}
Landraces are generally neglected by industrialized agriculture, regardless of their potential to provide valuable genetic material for breeding and to diversifying the available assortment for producers and markets. They may also excel in certain plant protection issues with possible resistance or tolerance to plant pathogens. This is the first report on the disease susceptibility traits of Hungarian on certain indeterminate and determinate tomato gene bank accessions under on-farm organic conditions. For this, a three-year on-farm experiment was conducted in two management systems, open-field and protected. Yield and disease symptoms data obtained from ten tomato landraces were compared to commercial varieties. The incidence and severity of three important diseases (caused by late blight 'Phytophthora infestans', early blight 'Alternaria solani' and Septoria leafspot 'Septoria lycopersici'), as well as yield, were recorded and assessed. According to these results, there were no significant difference between landraces and control varieties (San Marzano, Kecskeméti 549) regarding the studied parameters, and year was a determinant factor in the occurrence and severity of the infection of the studied diseases. In 2016, rainy, humid weather induced a severe late blight infection, causing serious damage to the open field, while the weather in 2015 and 2017 was favorable for tomato production and our measurements. There were some differences within and between landraces in terms of susceptibility. The investigation revealed that certain accessions can be highly recommended, e.g., the indeterminate 'Fadd' (RCAT030275) and 'Mátrafüred' (RCAT057656) had suitably high yields with significantly lower susceptibility to late blight, and the determinate 'Szentlőrinckáta' (RCAT078726) with high yield as well as tolerance to early blight is also recommendable, but it is sensitive to late blight under an adverse environment. This study suggests that landraces are competitive with the studied commercial varieties under organic production systems. Considering yield and the prevention of the major diseases of tomato, the studied tomato gene bank accessions are recommended for organic field and protected management systems.
\end{abstract}

Keywords: Solanum lycopersicum; landraces; on-farm trial; organic farming; Phytophthora infestans; Alternaria solani; Septoria lycopersici; yield; resistance 


\section{Introduction}

Tomato (Solanum lycopersicum L.) is a commercially important vegetable culture in many countries $[1,2]$. The advent of high-yielding cultivars and hybrids, as well as the changes in the social and financial situation of tomato growers, caused a shift in local agricultural production systems. The genetic diversity provided by landraces may allow crop improvement, conservation and sustainable use. Meanwhile, the landraces from market operations and home gardens have disappeared in favor of high-yielding cultivars substantially, which has narrowed down the genetic bases of cultivated tomatoes [3]. The improved farm biodiversity, a characteristic of organic operations, is well studied $[4,5]$. Among its cornerstones is to choose crop varieties that are well adapted for this type of cropping system. Although organic agriculture shows a significant development in terms of cultivation area and market, it still accounts for a small proportion of $\sim 1 \%$ of the overall agricultural production area on Earth [6]. Moreover, organic agriculture is still dependent on conventional plant varieties; around $95 \%$ of the varieties grown are derived from common commercial varieties [7-9]. Unfortunately, although the existence of a wide genetic diversity among tomato accessions provides the opportunities for the future genetic improvement of the crop [10], organic farm operations are usually too small for companies to invest into new varieties [11].

A widely accepted definition for landraces was created by Camacho Villa [12], a concept that integrates the earlier works of Harlan [13] and Hawkes [14]. A landrace is a cultivated plant with a historical origin and a recognizable identity that lacks any formal genetic improvement or breeding [12-16] These plants, as well as their wild crop relatives, possess a high genetic plasticity, expressed by a specific gene pool that represents a reservoir of diversity that can be tapped into by organisms to adapt to a changing environment, and breeders for crop improvement $[17,18]$. Landraces are well adapted to the area where they are cultivated, and are frequently associated with traditional farming systems. Not every landrace meets these characteristics, though [12]. Tomato landraces have a wider genetic base compared to modern improved genotypes, e.g., better performance under extreme weather conditions, such as water deficiency [19], improved flavor and nutrient quality [20]. It is still unknown whether the favorable potential tolerance and resistance of landraces can still be observed under current environmental and climatic conditions, using organic production methods, and if we cultivate them outside their original environment, similarly to this study.

Disease prevention is a major problem for organic farm operations due to the limited availability of plant protection strategies. Therefore, disease-resistance traits are highly valuable for growers [21-29]. Late blight (Phytophthora infestans (Mont.) de Bary), early blight (Alternaria solani Sorauer) and Septoria leaf spot (Septoria lycopersici Speg.) are among the most economically important diseases of tomato [30-33]. In the past, researchers have successfully used tomato landraces as sources of resistance against pathogens or diseases, such as Verticillium dahliae [34] or early blight [35]. Heirloom tomatoes were compared to hybrid varieties inside a high tunnel in organic production. No significant differences were found in terms of susceptibility against early blight [36]. In other cases, hybrid tomatoes proved to be more tolerant against late blight $[37,38]$. There are reports on Hungarian tomato landraces, with evaluated yield of determinate tomato gene bank accessions and consumer preferences to them [39] together with comprehensive measurements on the yield marketability, utility and nutritional properties of several indeterminate accessions [40-42]. However, the disease susceptibility of these accessions has not been analyzed to date. This study evaluated the yield and the disease tolerance of eight indeterminate and three determinate Hungarian tomato landraces compared to control varieties. This research was conducted to ascertain whether tomato landraces have economic potential for organic farming in Hungary. 


\section{Materials and Methods}

\subsection{Location}

The experiments were conducted on two organic farms, at Szigetmonostor $\left(47^{\circ} 41^{\prime} 44.99^{\prime \prime} \mathrm{N}\right.$, $19^{\circ} 5^{\prime} 47.18^{\prime \prime} \mathrm{E}$, coordinates according to WGS84 standard) and at Tahitótfalu $\left(47^{\circ} 45^{\prime} 14.08^{\prime \prime} \mathrm{N}\right.$, $\left.19^{\circ} 6^{\prime} 7.78^{\prime \prime} \mathrm{E}\right), 10 \mathrm{~km}$ apart, situated on the Szentendre Island (North of Budapest, Hungary) 100-124 m above sea level (Figure 1). Both farms are small family businesses that produce organic, seasonal vegetables in plastic tunnels at Szigetmonostor and in open fields, at Tahitótfalu, at 6 hectares since 2005 and at 1.5 hectares since 2010, respectively. These farms provide organic vegetables for local families in Community Supported Agriculture (CSA) system.

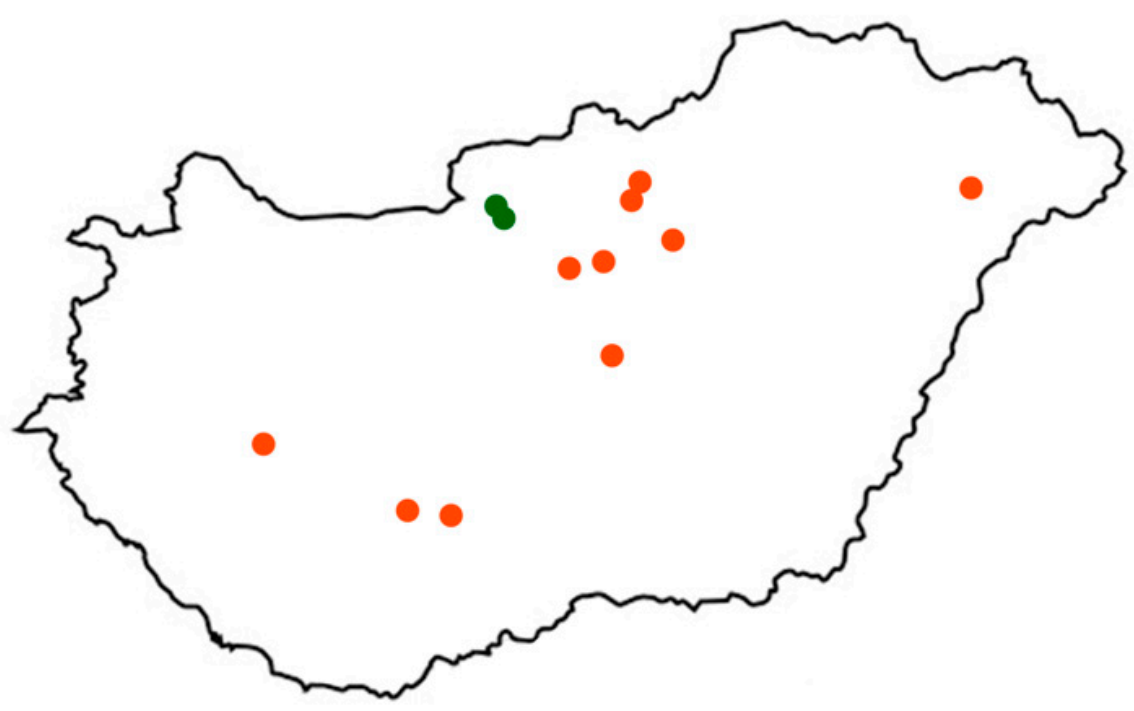

Figure 1. The places of origin of tomato gene bank accessions (red spots) and the locations of the experiment (green spots) in Hungary.

\subsection{Weather and Soil}

A weather station (in 2015-2016 iMetos (Pessl Instruments GmbH, Weiz, Austria; in 2017 Viking Art. 02036, Termometerfabriken Viking AB, Eskilstuna, Sweden) was used on the field to measure temperature, humidity and precipitation. In the plastic tunnel, data logger (in 2015-2016 Tlogg 160, Greisinger Electronic GmbH, Regenstauf, Germany in 2017 Voltcraft DL-120TH, Conrad Electronic SE, Hirschau, Germany) was used to measure temperature and humidity (Figure 2).

Both organic farms have alluvial soil. From each location, $1 \mathrm{~kg}$ representative soil samples were taken every September and investigated by the soil analysis laboratory of the Soil Conservation Directorate of Velence, Velence, Hungary, to determine the soil organic matter and nutrient availability of each experimental location (Table 1). 


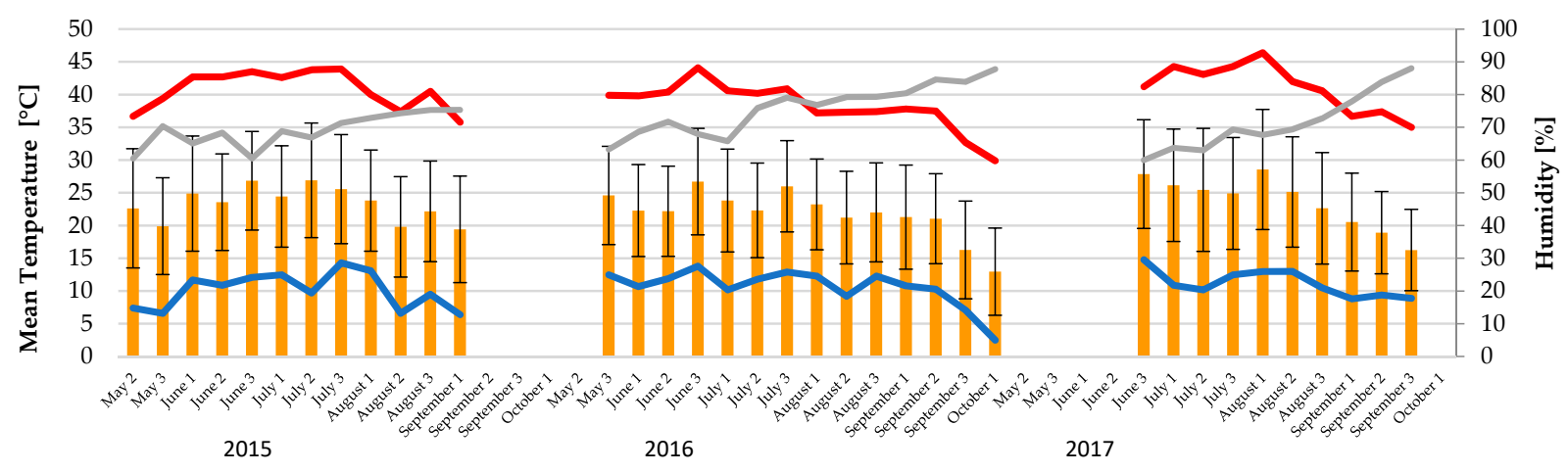

Decades

Mean temperature $\longrightarrow$ Minimum Temperature $\quad$ Maximum Temperature $\quad$ Mean Humidity

(a) Plastic tunnel, 2015-2107.
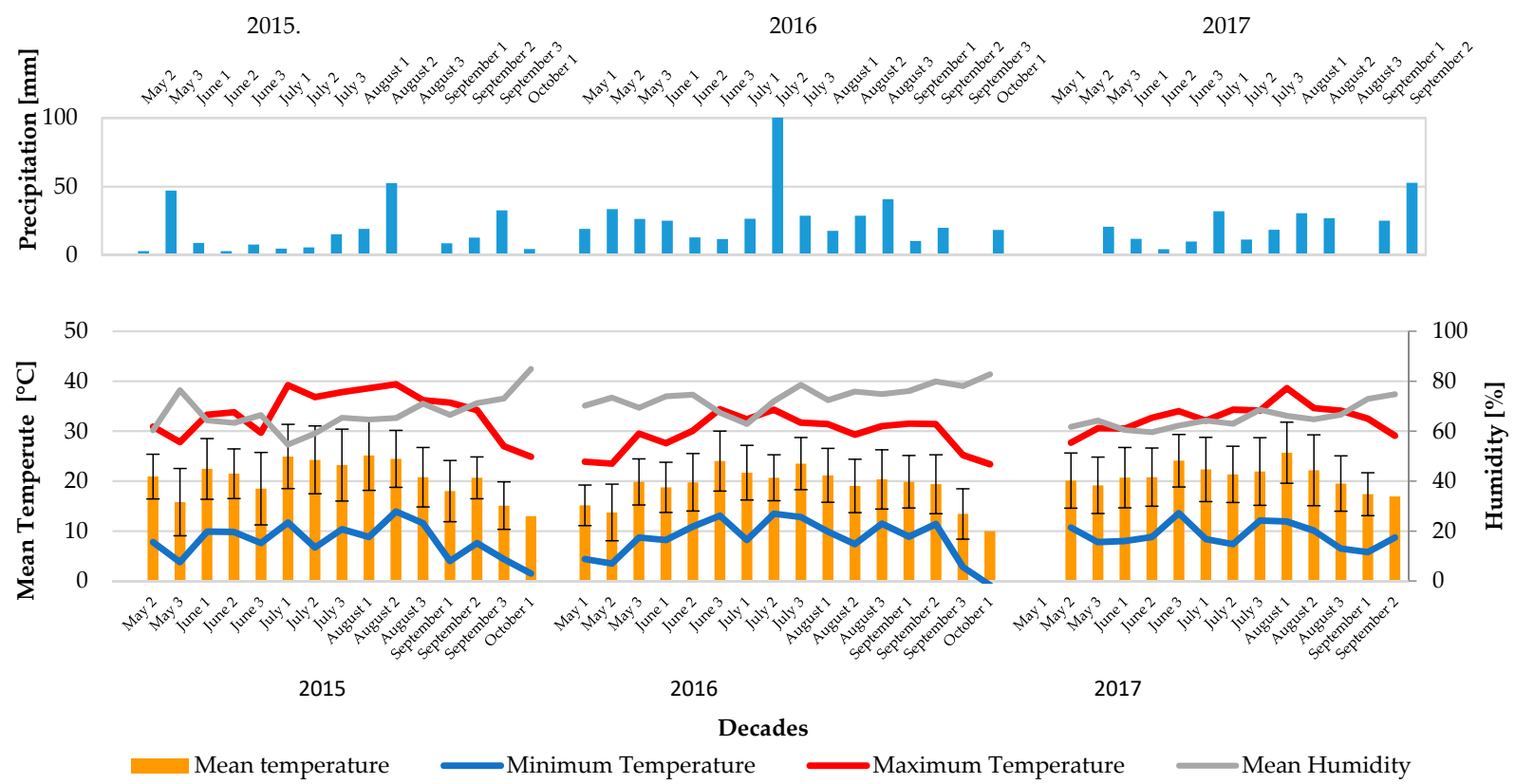

(b) Open field, 2015-2017.

Figure 2. Temperature $\left({ }^{\circ} \mathrm{C}\right)$ and relative humidity (\%) in 2015, 2016 and 2017 in the plastic tunnel (a) and open field (b) from the date of the planting to the end of the season. Seasons started according to the schedule of the farmers. Precipitation $(\mathrm{mm})$ was measured only on the open field (b).

Table 1. Soil parameters of the experimental locations in different years.

\begin{tabular}{ccccccc}
\hline \multirow{2}{*}{2015} & $\mathbf{p H}$ & $\mathbf{S O M}(\mathbf{\%})$ & $\mathbf{N}(\mathbf{p p m})$ & $\mathbf{P}(\mathbf{p p m})$ & $\mathbf{K}(\mathbf{p p m})$ \\
& $\begin{array}{l}\text { Plastic } \\
\text { tunnel }\end{array}$ & 7.47 & 2.31 & 20.6 & 250 & 372 \\
& Open field & 7.27 & 2.58 & 18 & 146 & 224 \\
\hline \multirow{2}{*}{2016} & $\begin{array}{l}\text { Plastic } \\
\text { tunnel }\end{array}$ & 7.42 & 2.53 & 176 & 643 & 562 \\
& Open field & 7.32 & 2.8 & 24.9 & 120 & 439 \\
\hline \multirow{2}{*}{2017} & Plastic & 7.26 & 2.74 & 42.8 & 703 & 326 \\
& $\begin{array}{c}\text { tunnel } \\
\text { Open field }\end{array}$ & 7.24 & 2.45 & 13.5 & 296 & 466 \\
\hline
\end{tabular}




\subsection{Landrace Accessions}

20 accessions were obtained from the National Centre for Biodiversity and Gene Conservation, Tápiószele, Hungary in 2011. After initial trials in an on-farm research network organized by the Hungarian Research Institute of Organic Agriculture involving a high number of farmers, the most popular and promising 10 accessions were chosen for this experiment with different consumption types, fruit shape and color (Table 2). Names of the accessions refer to the location (settlement) of origin (Figure 1).

Table 2. Tomato landraces and commercial (control) varieties used in the experiment.

\begin{tabular}{|c|c|c|c|c|c|c|}
\hline $\begin{array}{c}\text { Gene Bank } \\
\text { Accession Code }\end{array}$ & Name & Main Use & $\begin{array}{l}\text { Average Fruit } \\
\text { Weight (g) }\end{array}$ & Fruit Shape, Size & Growing Type & Location \\
\hline RCAT030566 & 'Balatonboglár' & $\begin{array}{l}\text { fresh consumption, } \\
\text { processing }\end{array}$ & $150-190$ & circular, medium & $\begin{array}{l}\text { Semi- } \\
\text { determinate, } \\
\text { determinate }\end{array}$ & $\mathrm{P}, \mathrm{O}$ \\
\hline RCAT030275 & ‘Cegléd’ & fresh consumption & $160-180$ & circular, medium & indeterminate & $\mathrm{P}, \mathrm{O}$ \\
\hline RCAT030373 & 'Fadd' & fresh consumption & $70-90$ & rectangular, medium & indeterminate & $\mathrm{P}, \mathrm{O}$ \\
\hline RCAT031257 & ‘Gyöngyös' & salad & $150-200$ & cylindrical, medium & indeterminate & $\mathrm{P}, \mathrm{O}$ \\
\hline RCAT030731 & ‘Máriapócs' & fresh consumption & $15-20$ & circular, small & indeterminate & $\mathrm{P}, \mathrm{O}$ \\
\hline RCAT057656 & ‘Mátrafüred' & processing & $300-320$ & heart-shaped, large & indeterminate & $\mathrm{P}, \mathrm{O}$ \\
\hline RCAT030370 & ‘Tarnaméra' & processing & $50-70$ & cylindrical, medium & indeterminate & $\mathrm{P}, \mathrm{O}$ \\
\hline RCAT030184 & 'Tolna megye' & processing & $300-350$ & slightly flattened, large & indeterminate & $\mathrm{P}, \mathrm{O}$ \\
\hline RCAT057829 & 'Dány' & processing & $110-130$ & circular, medium & determinate & $\mathrm{O}$ \\
\hline RCAT078726 & 'Szentlőrinckáta' & processing & $50-55$ & ovate, medium & determinate & $\mathrm{O}$ \\
\hline n.a. (control)) & 'San Marzano' & processing & $100-110$ & cylindrical, medium & indeterminate & $\mathrm{P}, \mathrm{O}$ \\
\hline n.a. (control) & 'Kecskeméti 549’ & processing & $50-60$ & ovate, medium & determinate & $\mathrm{O}$ \\
\hline
\end{tabular}

Fruit shape (in longitudinal section) and size are described according to UPOV (2001) guidelines (TG/44/10). P: plastic tunnel; O: open field.

\subsection{Plant Material and Planting}

Landraces were maintained by collecting the seeds from their mature fruit every year. Seeds were sown in plastic starter trays, in a potting medium of peat and compost at 1:1. Seedlings with 2 leaves were transplanted into $7 \times 7 \times 7 \mathrm{~cm}$ pots and nursed until the date of planting in an unheated plastic tunnel at the Experimental and Educational Field of the Hungarian University of Agriculture and Life Sciences (formerly Szent István University), Department of Organic Farming, in Budapest. The farm has been certified as organic since 1991. Due to different weather conditions, dates of sowing and planting were different for each year (Table 3).

Table 3. Date of sowing and planting.

\begin{tabular}{ccc}
\hline Year. & Sowing & Planting \\
\hline 2015 & 20 March & 18 May \\
2016 & 16 March & 25 May \\
2017 & 12 March & 29 May. \\
\hline
\end{tabular}

\subsection{Farming Methods and Agrotechnical Work}

At one of the locations, in the plastic tunnel, each plant was pruned to one stem and tied with a string to a wire that ran over each line. Black plastic was used to cover each row, with drip irrigation lines running underneath. Irrigation water contained dissolved chicken manure. Sucker stems were pruned weekly. Hoes were used for weeding. As an on-farm experiment, each farmer used their own farming methods, and a plant protection program (copper fungicide and use of biological control agents instead of chemical pesticides) was carried out in agreement with the farmers that was consistent during the years at each plot.

At the other location, on the open field, $200 \mathrm{~cm}$ long bamboo stakes were used as supports for each indeterminate tomato plant. They were all pruned to one stem. Determinate plants were tied to a $100 \mathrm{~cm}$ long stake, and they were not pruned. Sucker stems were removed approximately every 2 weeks. A small cultivator and hoe were used for weeding. Drip irrigation was installed to water the tomato plants. Farming methods 
(e.g., crop rotation and organic plant protection) were applied in both locations according to European Regulation (EC) no. 834/2007.

\subsection{Experimental Design}

The experiment was carried out in two management systems, in a plastic tunnel and on the open field. The plastic tunnel was $40 \mathrm{~m}$ long and $5 \mathrm{~m}$ wide. Nine indeterminate tomato landraces and one control variety (Table 1) were tested here in a randomized block design with 3 replicates. Each unit in the repetition contained 12 plants (in a layout of $2 \times 6$ ). Spacing between plants was $50 \times 60 \mathrm{~cm}$, in a diagonal layout. Each plot measured $3.6 \mathrm{~m}^{2}$, with the adjacent walkways.

On the open field, the experiment was set in a randomized complete block design with four replicates. Each plot $\left(4.9 \mathrm{~m}^{2}\right)$ contained 10 plants (in a layout of $2 \times 5$ plants). Spacing between plants was $70 \times 70 \mathrm{~cm}$.

Different tomato gene bank items and control varieties were used in a plastic tunnel and on the open field (Table 2), since management and environmental parameters are different in these two locations.

\subsection{Disease and Yield Evaluation}

Yield evaluation: As an on-farm experiment, the date of harvest was determined together with the farmer. Picking of the ripened fruits was performed on a weekly basis or adjusted to the farmer's demand. Each plot was harvested separately and was measured with a field scale (Demandy H7).

Tomato plants were regularly monitored for disease symptoms associated with Phytophthora infestans, Alternaria solani and Septoria lycopersici symptoms during the season. Late blight symptoms on fruits and leaves were evaluated according to the scale described in Horneburg et al. [43] in a scale of 1-9, where 1 refers to no infection, while 9 means all leaves are dead. Symptoms of early blight and tomato leaf spot disease were evaluated based on a percentage scale that measured the total infected leaf area.

\subsection{Statistical Methods}

The data collected from the experiments on field and in the plastic tunnel were analyzed separately. Yield data and infection data were also analyzed separately. Variables were named as yield ('Y'), Alternaria ('A'), Phytophthora infection on leaf ('PL'), Phytophthora infection on fruit ('PF') and Septoria ('S') together with the day after planting (DAP) (e.g., Y84: yield data collected on the 84th day after planting).

First, principal component analysis (PCA) was performed for the three years to reduce the number of explaining variables. In the case of the yield data of the 2016 open-field experiment, there were only 2 variables (Y76 and Y90), so instead of PCA, we used the original variables later on. Thus, 11 PCA models were developed (with yield or infection variables; for three years, open-field and plastic tunnel experiments: $2 \times 3 \times 2-1=11$ ). All variables had their communalities above 0.3 . Based on the explained variance rate, we kept two or three principal components (PCs). The Ward method was used to identify the correlation coefficients with the highest loadings for each PC. Based on these, PCs were given names.

Next, we took the PC factor scores as dependent variables as well as the two original variables of open-field yield in 2016 (again, as dependent variables), and applied one-way multivariate ANOVA (one-way MANOVA) to determine the overall differences between the landraces (factor = landrace). The normality of the residuals was accepted by their skewness and kurtosis, as their absolute values were all below 1 . The homogeneity of variances was checked by Levene's test. We evaluated the unexplained variance rate (Wilk's $\lambda$ ). In case this overall MANOVA test was significant, we performed one-way follow-up ANOVA for each PC, separately with Bonferroni's correction. Next, for the significant PCs, post hoc tests were used. Since the homogeneity of variances was violated in some cases, we separated the homogeneous groups by Games-Howell's post hoc test 
to reduce the Type I error in the case of heteroscedasticity. Statistical software IBM SPSS Statistics 25 (Armonk, New York, NY, USA, 2017) was used for statistical analysis.

\section{Results}

The results of the principal component analysis are reported separately for plastic tunnel and open-field experiments and years. The variance explained by the principal components (PCs) as well as the total explained variance rate is shown. To understand the information content of the PCs, the original variables that are highly correlated with the PCs (with high loadings) are also given. We named the PCs, and in the following, we refer to them by these names. Wilk's $\lambda$ (unexplained variance rate) values and their $F$ tests of significance as the overall MANOVA results are shown too. In Tables 4, 6, 8 and 10, the PCA results while in Tables 5, 7, 9 and 11, the post hoc test results of the significant PCs (revealed by the follow-up one-way ANOVA) are presented. Different letters represent significantly different groups (Games-Howell's post hoc $p<0.05$ ).

\subsection{Yield}

\subsubsection{Plastic Tunnel}

In 2015, the PCs of the 'early' and 'late season' yields were significantly different (Table 4). The early season of 2015 (Table 5), 'Máriapócs' and the control variety 'San Marzano' had the lowest yield in the plastic tunnel, while 'Cegléd' and 'Tolna megye' had the highest significant yield (Figure 3a, Table 5). Later in the season, 'Mátrafüred' and 'Tarnaméra' gave a significantly lower yield than 'Balatonboglár' and 'San Marzano'. In 2016, only one PC referred to as 'early season' showed a significant difference (Figure 3b). In this period, 'San Marzano' and 'Máriapócs' had significantly lower yield than 'Balatonboglár' and 'Fadd', but 'Mátrafüred' gave the greatest significant amount; however, the total yield of all varieties was far lower compared to years 2015 and 2017 (Figure 3a,c). In 2017, based on the PCs of the two early periods (F1, F2) in Table 4, the rankings were different, but 'Fadd' had a significantly lower yield in both cases; 'Balatonboglár' resulted in the highest yield at the earliest stage (F3); 'Tolna megye' and 'Mátrafüred' performed better in the next stage (F2). In the late season, only the lowest yield of 'Máriapócs' was significant; and the yields of the other landraces were similar with no significant differences.

Table 4. The results of the principal component analysis for the yield of the plastic tunnel experiment: the explained variances of the PCs as well as the total explained variance rates; the original variables that are highly correlated with the PCs (with high loadings) and the names that refer to the PCs later on; Wilk's $\lambda$ (unexplained variance rate) values (overall MANOVA results) and the follow-up ANOVA tests (between-subject effects) with F values and their significances.

\begin{tabular}{|c|c|c|c|c|c|c|c|}
\hline \multirow{2}{*}{ 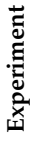 } & \multirow[b]{2}{*}{ Year } & \multicolumn{3}{|c|}{ PCA } & \multicolumn{2}{|c|}{ MANOVA with Factor 'Varieties' } & \multirow[b]{2}{*}{$\begin{array}{c}\text { Between-Subject } \\
\text { Effects } \\
\text { F(8;18) }\end{array}$} \\
\hline & & $\begin{array}{c}\text { PCA } \\
\text { Total Variance } \\
\text { Explained \% }\end{array}$ & $\begin{array}{c}\text { Principal } \\
\text { Components } \\
\text { (Explained } \\
\text { Variances \%) }\end{array}$ & $\begin{array}{l}\text { Highly } \\
\text { Correlated } \\
\text { Explaining } \\
\text { Variables } \\
\end{array}$ & Referred to as & Wilk's $\lambda$ & \\
\hline \multirow{9}{*}{ 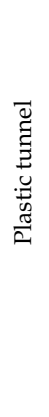 } & \multirow{3}{*}{2015} & \multirow{3}{*}{$74.64 \%$} & $\mathrm{~F} 1(39.11 \%)$ & Y72, Y79, Y86 & 'Yield_2015_early' & \multirow{2}{*}{$0.01 * * *$} & $35.24^{* * *}$ \\
\hline & & & $\mathrm{F} 2(18.73 \%)$ & Y100, Y106 & 'Yield_2015_late' & & $3.48 *$ \\
\hline & & & $\mathrm{F} 3(16.79 \%)$ & Y92 & 'Yield_2015_DAP92' & & $3.16^{\mathrm{ns}}$ \\
\hline & \multirow{3}{*}{2016} & \multirow{3}{*}{$78.65 \%$} & $\mathrm{~F} 1(33.04 \%)$ & Y76, Y84, Y91 & 'Yield_2016_early' & \multirow{3}{*}{$<0.001 * * *$} & $11.19^{* * *}$ \\
\hline & & & $\mathrm{F} 2(25.62 \%)$ & Y98, Y112 & 'Yield_2016_late' & & $1.84^{\mathrm{ns}}$ \\
\hline & & & F3(19.99\%) & Y105 & 'Yield_2016_DAP105' & & $0.83^{\mathrm{ns}}$ \\
\hline & \multirow{3}{*}{2017} & \multirow{3}{*}{$67.07 \%$} & $\mathrm{~F} 1(32.25 \%)$ & $\begin{array}{c}\text { Y80, Y100, Y107, } \\
\text { Y114 }\end{array}$ & 'Yield_2017_late' & \multirow{3}{*}{$0.07 * * *$} & $6.41 * * *$ \\
\hline & & & $\mathrm{F} 2(21.60 \%)$ & Y73, Y93 & 'Yield_2017_early2' & & $17.24^{* * *}$ \\
\hline & & & $\mathrm{F} 3(13.22 \%)$ & Y66, Y84 & 'Yield_2017_early1' & & $3.45 *$ \\
\hline
\end{tabular}

Follow-up ANOVA with Bonferroni's Type I error correction: ${ }^{*}$ significant at $p<0.05 ;{ }^{* * *}$ significant at $p<0.001$; ${ }^{\text {ns }}$ not significant. Yield $\left({ }^{\prime} Y^{\prime}\right)$; numbers after the names represent the day after planting (DAP). According to between-subject effects, significant PCs are in bold. 
Table 5. The post hoc test results of the significant PCs obtained from the yield data of the different tomato gene bank items and control varieties regarding the plastic tunnel experiment. Different letters from lower to higher yields represent significantly different groups (Games-Howell's, $p<0.05$ ). Abbreviations of the Hungarian landrace gene bank items are: B: 'Balatonboglár'; C: 'Cegléd'; F: 'Fadd'; GY: ‘Gyöngyös'; MR: 'Máriapócs'; MT: 'Mátrafüred'; TA: 'Tarnaméra'; TO: ‘Tolna megye'. The control variety is SA: 'San Marzano'. Control accessions are highlighted with grey background color.

\begin{tabular}{|c|c|c|c|c|c|c|c|c|c|c|c|c|}
\hline Experiment & \multirow{3}{*}{$\begin{array}{l}\text { Year } \\
2015\end{array}$} & \multirow{2}{*}{$\begin{array}{c}\begin{array}{c}\text { Principal } \\
\text { Compo- } \\
\text { nent }\end{array} \\
\text { F1 }\end{array}$} & \multirow{2}{*}{$\begin{array}{l}\text { Referred to as... } \\
\text { 'Yield_2015_early' }\end{array}$} & \multicolumn{9}{|c|}{ Pairwise Comparisons } \\
\hline \multirow{6}{*}{ 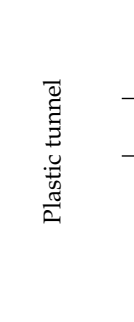 } & & & & $\begin{array}{c}\text { MR } \\
\text { a }\end{array}$ & $\begin{array}{c}\text { SA } \\
\text { a }\end{array}$ & $\begin{array}{l}\text { TA } \\
\mathrm{ab}\end{array}$ & $\begin{array}{c}\mathrm{F} \\
\mathrm{abc}\end{array}$ & $\begin{array}{c}\mathrm{B} \\
\mathrm{abc}\end{array}$ & $\begin{array}{l}\text { GY } \\
\text { bcd }\end{array}$ & $\begin{array}{l}\text { MT } \\
\text { bcd }\end{array}$ & $\begin{array}{c}\mathrm{C} \\
\mathrm{cd}\end{array}$ & $\begin{array}{c}\mathrm{TO} \\
\mathrm{d}\end{array}$ \\
\hline & & F2 & 'Yield_2015_late' & $\begin{array}{c}\text { MT } \\
\text { a }\end{array}$ & $\begin{array}{l}\text { TA } \\
a b\end{array}$ & $\begin{array}{c}\text { MR } \\
\text { a }\end{array}$ & $\begin{array}{l}\mathrm{C} \\
\mathrm{a}\end{array}$ & $\begin{array}{c}\text { GY } \\
a b\end{array}$ & $\begin{array}{l}\mathrm{TO} \\
\mathrm{ab}\end{array}$ & $\begin{array}{c}\mathrm{F} \\
\mathrm{ab}\end{array}$ & $\begin{array}{l}\mathrm{B} \\
\mathrm{b}\end{array}$ & $\begin{array}{c}\text { SA } \\
\text { b }\end{array}$ \\
\hline & 2016 & F1 & 'Yield_2016_early' & $\begin{array}{c}\text { SA } \\
\mathrm{a}\end{array}$ & $\begin{array}{c}\text { MR } \\
\text { a }\end{array}$ & $\begin{array}{l}\text { TA } \\
\text { ab }\end{array}$ & $\begin{array}{l}\text { GY } \\
a b\end{array}$ & $\begin{array}{c}\mathrm{C} \\
\mathrm{ab}\end{array}$ & $\begin{array}{l}\mathrm{B} \\
\mathrm{b}\end{array}$ & $\begin{array}{l}\mathrm{F} \\
\mathrm{b}\end{array}$ & $\begin{array}{l}\text { TO } \\
\text { bc }\end{array}$ & $\begin{array}{c}\text { MT } \\
\text { c }\end{array}$ \\
\hline & & F1 & 'Yield_2017_late' & $\begin{array}{c}\text { MR } \\
\text { a }\end{array}$ & $\begin{array}{c}\mathrm{B} \\
\mathrm{ab}\end{array}$ & $\begin{array}{c}\mathrm{C} \\
\mathrm{ab}\end{array}$ & $\begin{array}{c}\text { SA } \\
\text { b }\end{array}$ & $\begin{array}{c}\text { TA } \\
\text { b }\end{array}$ & $\begin{array}{c}\mathrm{GY} \\
\mathrm{b}\end{array}$ & $\begin{array}{c}\text { MT } \\
\text { b }\end{array}$ & $\begin{array}{l}\mathrm{F} \\
\mathrm{b}\end{array}$ & $\begin{array}{c}\mathrm{TO} \\
\mathrm{b}\end{array}$ \\
\hline & 2017 & F2 & 'Yield_2017_early2' & $\begin{array}{l}\mathrm{F} \\
\mathrm{a}\end{array}$ & $\begin{array}{l}\text { GY } \\
a b\end{array}$ & $\begin{array}{c}\text { B } \\
\text { bc }\end{array}$ & $\begin{array}{l}\text { SA } \\
\text { bc }\end{array}$ & $\begin{array}{c}\text { MR } \\
\text { cd }\end{array}$ & $\begin{array}{l}\text { TA } \\
\text { cd }\end{array}$ & $\begin{array}{l}\mathrm{C} \\
\mathrm{cd}\end{array}$ & $\begin{array}{c}\text { MT } \\
\text { d }\end{array}$ & $\begin{array}{c}\mathrm{TO} \\
\mathrm{d}\end{array}$ \\
\hline & & F3 & 'Yield_2017_early1' & $\begin{array}{c}\text { MT } \\
\text { a }\end{array}$ & $\begin{array}{l}\mathrm{F} \\
\mathrm{a}\end{array}$ & $\begin{array}{c}\text { MR } \\
\text { a }\end{array}$ & $\begin{array}{l}\mathrm{C} \\
\mathrm{a}\end{array}$ & $\begin{array}{l}\mathrm{TO} \\
\mathrm{ab}\end{array}$ & $\begin{array}{c}\text { GY } \\
a b\end{array}$ & $\begin{array}{l}\text { TA } \\
\mathrm{ab}\end{array}$ & $\begin{array}{c}\text { SA } \\
a b\end{array}$ & $\begin{array}{l}\text { B } \\
\text { b }\end{array}$ \\
\hline
\end{tabular}

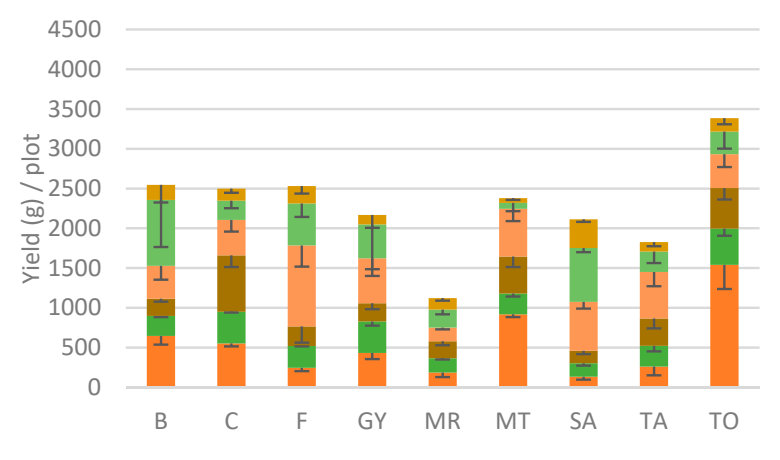

(a) Plastic tunnel, 2015

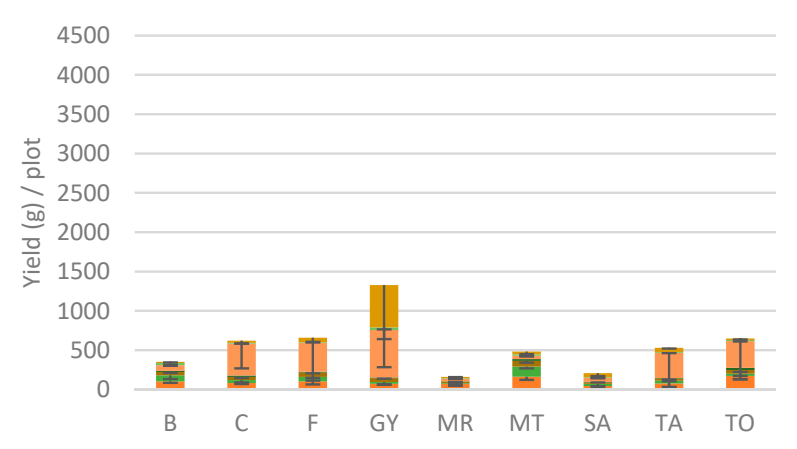

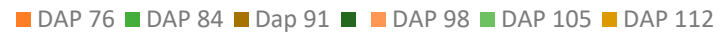

(b) Plastic tunnel, 2016

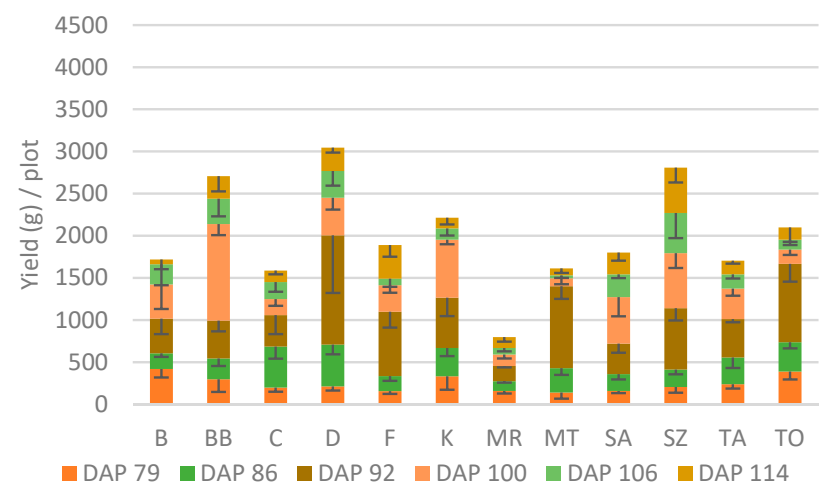

(d) Open field, 2015

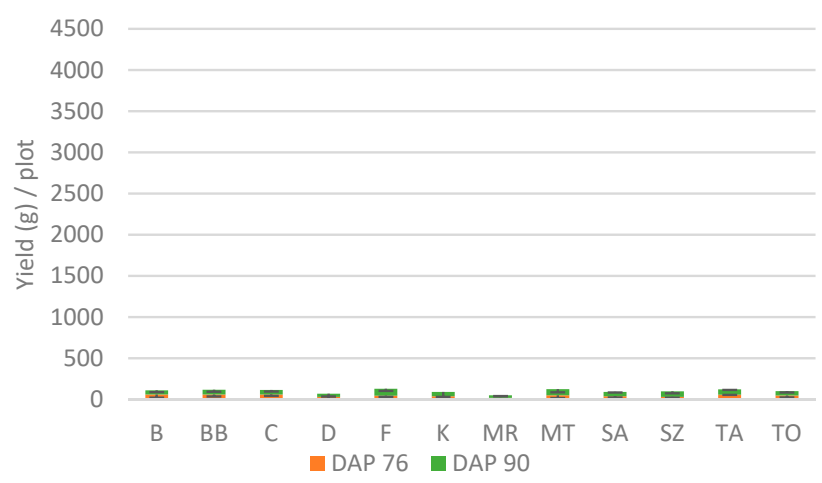

(e) Open field, 2017

Figure 3. Cont. 


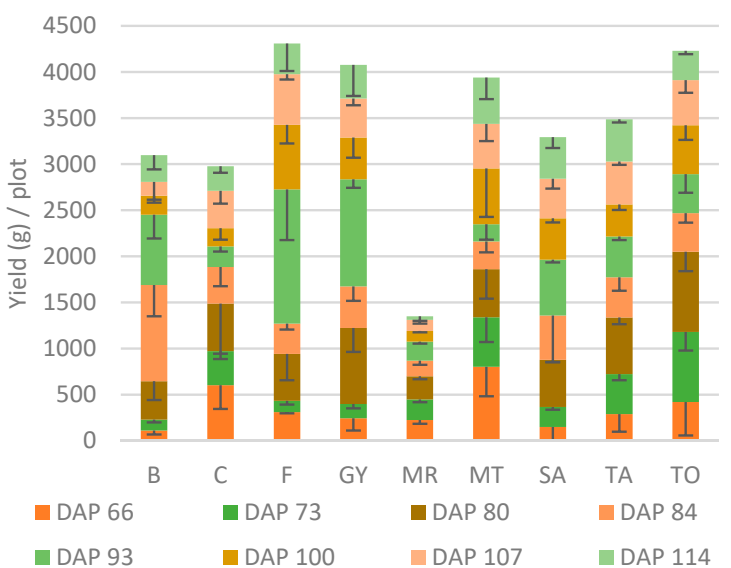

(c) Plastic tunnel, 2017

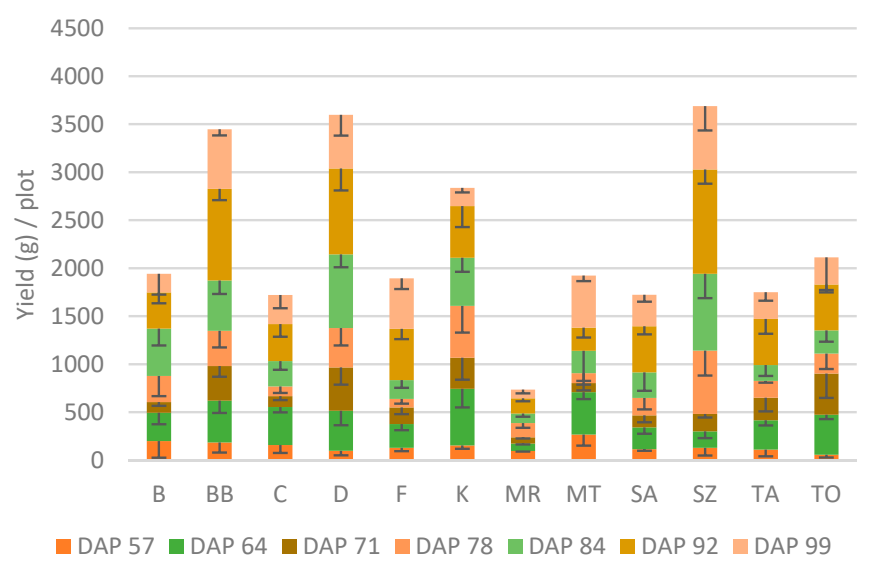

(f) Open field, 2017

Figure 3. Average yield data per plot of the different tomato gene bank accessions and control varieties in plastic tunnel and on open field. Stacked columns are divided by day after planting (DAP); error bars are minus direction of standard deviation. B: ‘Balatonboglár'; C: ‘Cegléd'; F: ‘Fadd'; GY: ‘Gyöngyös'; MR: 'Máriapócs'; MT: 'Mátrafüred'; TA: ‘Tarnaméra'; TO: ‘Tolna megye'; SA: ‘San Marzano'; BB: ‘Balatonboglár'; D: ‘Dány'; SZ: ‘Szentlőrinckáta'; K: ‘Kecskeméti 549'. Control varieties are in bold.

\subsubsection{Open Field}

In general, determinate tomato accessions had significantly higher yields than the indeterminate ones on the open field (Figure 3d,f). In 2015 and 2017, 'early' and 'late' periods were separated significantly, while in 2016, the two periods showed no significant differences. (Table 6). The late season of 2015 (F1) was differentiated most significantly by the accessions, where open-field indeterminate tomato accessions, especially 'Mátrafüred', resulted in a significantly lower yield than the determinate ones. 'Szentlörinckáta' (Table 7) performed significantly better, and this difference was shown in the first and early periods as well. 'Fadd' had a worse yield in the first period (F3), while 'Máriapócs' had a significantly lower yield in the early period (F2). 'Dány' and 'Balatonboglár' gave higher yields in the first two periods (F2, F3), respectively. In 2016, due to a serious infestation by Phytophthora infestans, almost no yield was harvested (Figure 3e). In 2017, only 'Máriapócs' gave a significantly lower yield in the early period (F2), while 'Mátrafüred', and the control variety, 'Kecskeméti 549', had better yields than any other accessions; in the late period (F1), 'Szentlőrinckáta' was significantly outstanding.

Table 6. The results of the principal component analysis for the yield of the open-field experiment: the explained variances of the PCs as well as the total explained variance rates; the original variables that are highly correlated with the PCs (with high loadings) and the names that refer to the PCs later on; Wilk's $\lambda$ (unexplained variance rate) values (overall MANOVA results) and the follow-up ANOVA tests (between-subject effects) with F values and their significances.

\begin{tabular}{|c|c|c|c|c|c|c|c|}
\hline \multirow{2}{*}{ 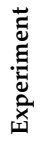 } & \multirow[b]{2}{*}{ Year } & \multicolumn{3}{|c|}{ PCA } & \multicolumn{2}{|c|}{ MANOVA with Factor 'Varieties' } & \multirow[b]{2}{*}{$\begin{array}{c}\text { Between-Subject } \\
\text { Effects } \\
\text { F(11;36) }\end{array}$} \\
\hline & & $\begin{array}{c}\text { PCA } \\
\text { Total Variance } \\
\text { Explained \% }\end{array}$ & $\begin{array}{c}\text { Principal } \\
\text { Components } \\
\text { (Explained } \\
\text { Variances \%) }\end{array}$ & $\begin{array}{c}\text { Highly } \\
\text { Correlated } \\
\text { Explaining } \\
\text { Variables }\end{array}$ & Referred to as & Wilk's $\lambda$ & \\
\hline \multirow{7}{*}{ 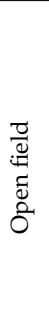 } & \multirow{3}{*}{2015} & \multirow{3}{*}{$74.55 \%$} & $\mathrm{~F} 1(30.00 \%)$ & Y100, Y106, Y114 & 'Yield_2015_late' & \multirow{2}{*}{$0.02 * * *$} & $11.14^{* * *}$ \\
\hline & & & $\mathrm{F} 2(23.66 \%)$ & Y86, Y92 & 'Yield_2015_early' & & $8.34^{* * *}$ \\
\hline & & & F3(20.89\%) & Y79 & 'Yield_2015_first' & & $6.50 * * *$ \\
\hline & \multirow{2}{*}{2016} & \multirow{2}{*}{\multicolumn{3}{|c|}{$\begin{array}{c}\text { Instead of PCA, MANOVA was performed } \\
\text { with the original variables Y76, Y90 }\end{array}$}} & 'Yield_2016_DAP76' & \multirow{2}{*}{$0.55^{\text {ns }}$} & - \\
\hline & & & & & 'Yield_2016_DAP90' & & - \\
\hline & \multirow{2}{*}{2017} & \multirow[t]{2}{*}{$74.55 \%$} & $\mathrm{~F} 1(30.00 \%)$ & $\begin{array}{c}\text { Y71, Y78, Y84, } \\
\text { Y92, Y99 }\end{array}$ & 'Yield_2017_late' & \multirow{2}{*}{$0.05^{* * *}$} & $16.18^{* * *}$ \\
\hline & & & $\mathrm{F} 2(23.66 \%)$ & Y57, Y64 & 'Yield_2017_early' & & $6.29 * * *$ \\
\hline
\end{tabular}

Follow-up ANOVA with Bonferroni's Type I error correction: ${ }^{* * *}$ significant at $p<0.001$; ${ }^{\text {ns }}$ not significant. Yield ('Y'); numbers after the names represent the day after planting (DAP). According to between-subject effects, significant PCs are in bold. 
Table 7. The post hoc test results of the significant PCs obtained from the yield data of the different tomato gene bank items and control varieties regarding the open-field experiment. Different letters from lower to higher yields represent significantly different groups (Games-Howell's, $p<0.05)$. Abbreviations of the Hungarian gene bank items are: B: 'Balatonboglár'; C: 'Cegléd'; F: ‘Fadd'; GY: 'Gyöngyös'; MR: 'Máriapócs'; MT: 'Mátrafüred'; TA: ‘Tarnaméra'; TO: ‘Tolna megye'. The control variety is SA: 'San Marzano'. Determinate gene bank items: BB: ‘Balatonboglár'; D: 'Dány'; SZ: 'Szentlőrinckáta. The control variety is K: 'Kecskeméti 549 '. Control varieties are highlighted with grey background color.

\begin{tabular}{|c|c|c|c|c|c|c|c|c|c|c|c|c|c|c|c|}
\hline Experiment & Year & $\begin{array}{l}\text { Principal } \\
\text { Compo- }\end{array}$ & Referred as & & & & & Pairv & se Cor & parisor & & & & & \\
\hline \multirow{6}{*}{ 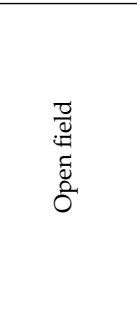 } & \multirow{3}{*}{2015} & F1 & 'Yield_2015_late' & $\begin{array}{c}\text { MT } \\
\text { a }\end{array}$ & $\begin{array}{c}\text { MR } \\
\mathrm{ab}\end{array}$ & $\begin{array}{l}\text { TO } \\
a b c\end{array}$ & $\begin{array}{c}\mathrm{C} \\
\mathrm{abc}\end{array}$ & $\begin{array}{l}\text { TA } \\
\mathrm{abc}\end{array}$ & $\begin{array}{c}F \\
a b c\end{array}$ & $\begin{array}{c}\mathrm{B} \\
\mathrm{abc}\end{array}$ & $\begin{array}{l}\mathrm{K} \\
\mathrm{bc}\end{array}$ & $\begin{array}{l}\text { SA } \\
\text { cd }\end{array}$ & $\begin{array}{c}\mathrm{D} \\
\text { cde }\end{array}$ & $\begin{array}{l}\text { BB } \\
\text { de }\end{array}$ & $\begin{array}{c}\text { SZ } \\
\mathrm{e}\end{array}$ \\
\hline & & F2 & 'Yield_2015_early' & $\begin{array}{c}\text { MR } \\
a\end{array}$ & $\begin{array}{l}\mathrm{SA} \\
\mathrm{ab}\end{array}$ & $\begin{array}{c}\mathrm{B} \\
\mathrm{ab}\end{array}$ & $\begin{array}{l}\mathrm{BB} \\
\mathrm{ab}\end{array}$ & $\begin{array}{c}\mathrm{F} \\
\mathrm{ab}\end{array}$ & $\begin{array}{l}\text { TA } \\
\mathrm{ab}\end{array}$ & $\begin{array}{l}\mathrm{SZ} \\
\mathrm{ab}\end{array}$ & $\begin{array}{l}\mathrm{K} \\
\mathrm{ab}\end{array}$ & $\begin{array}{c}\mathrm{C} \\
\mathrm{bc}\end{array}$ & $\begin{array}{l}\text { MT } \\
\text { bc }\end{array}$ & $\begin{array}{l}\mathrm{TO} \\
\mathrm{bc}\end{array}$ & $\begin{array}{l}\mathrm{D} \\
\mathrm{c}\end{array}$ \\
\hline & & F3 & 'Yield_2015_first' & $\begin{array}{l}\mathrm{F} \\
\mathrm{a}\end{array}$ & $\begin{array}{c}\mathrm{SZ} \\
\mathrm{a}\end{array}$ & $\begin{array}{l}\text { MT } \\
\text { ab }\end{array}$ & $\begin{array}{l}\text { MR } \\
\text { abc }\end{array}$ & $\begin{array}{l}\text { SA } \\
\mathrm{abc}\end{array}$ & $\begin{array}{c}\mathrm{D} \\
\mathrm{abc}\end{array}$ & $\begin{array}{c}\mathrm{C} \\
\mathrm{abcd}\end{array}$ & $\begin{array}{c}\text { TA } \\
\text { abcd }\end{array}$ & $\begin{array}{c}\text { TO } \\
\text { bcd }\end{array}$ & $\begin{array}{l}\text { BB } \\
\text { bcd }\end{array}$ & $\begin{array}{c}\mathrm{K} \\
\mathrm{cd}\end{array}$ & $\begin{array}{l}\mathrm{B} \\
\mathrm{d}\end{array}$ \\
\hline & 2016 & \multicolumn{14}{|c|}{ no significant differences were detected } \\
\hline & \multirow{2}{*}{2017} & F1 & 'Yield_2017_late' & $\begin{array}{c}\mathrm{MR} \\
\mathrm{a}\end{array}$ & $\begin{array}{l}\text { MT } \\
\text { ab }\end{array}$ & $\begin{array}{c}\mathrm{C} \\
\mathrm{ab}\end{array}$ & $\begin{array}{c}\mathrm{SA} \\
\mathrm{ab}\end{array}$ & $\begin{array}{l}\text { TA } \\
\mathrm{ab}\end{array}$ & $\begin{array}{c}\mathrm{B} \\
\mathrm{ab}\end{array}$ & $\begin{array}{c}\mathrm{F} \\
\mathrm{ab}\end{array}$ & $\begin{array}{l}\text { TO } \\
\text { bc }\end{array}$ & $\begin{array}{c}\mathrm{K} \\
\text { bcd }\end{array}$ & $\begin{array}{l}\text { BB } \\
\text { cde }\end{array}$ & $\begin{array}{l}\mathrm{D} \\
\mathrm{de}\end{array}$ & $\begin{array}{c}\mathrm{SZ} \\
\mathrm{e}\end{array}$ \\
\hline & & F2 & 'Yield_2017_early' & $\begin{array}{c}\text { MR } \\
\text { a }\end{array}$ & $\begin{array}{l}\mathrm{SZ} \\
\mathrm{ab}\end{array}$ & $\begin{array}{l}\text { SA } \\
\text { abc }\end{array}$ & $\begin{array}{c}\mathrm{F} \\
\mathrm{abc}\end{array}$ & $\begin{array}{c}\text { TA } \\
\text { abcd }\end{array}$ & $\begin{array}{c}\text { TO } \\
\text { abcd }\end{array}$ & $\begin{array}{c}\mathrm{D} \\
\mathrm{abcd}\end{array}$ & $\begin{array}{c}\mathrm{B} \\
\mathrm{abcd}\end{array}$ & $\begin{array}{c}\mathrm{C} \\
\text { bcd }\end{array}$ & $\begin{array}{l}\mathrm{BB} \\
\mathrm{cd}\end{array}$ & $\begin{array}{c}\text { MT } \\
\text { d }\end{array}$ & $\begin{array}{l}\mathrm{K} \\
\mathrm{d}\end{array}$ \\
\hline
\end{tabular}

\subsection{Diseases}

To support the statistical results of the disease symptoms, a heat map is attached (Figure 4) to help visualize the disease severity and show average values on the studied gene bank accessions and control varieties, in a timeline measured by days after planting.

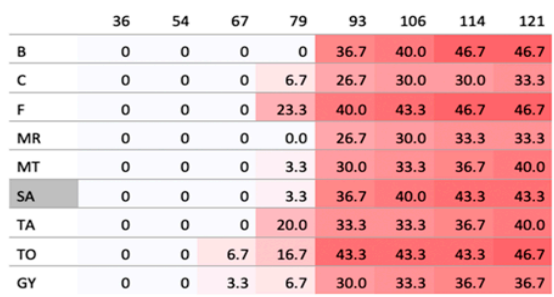

a) 2015, Plastic tunnel, Days After Planting (DAP), Alternaria (red)

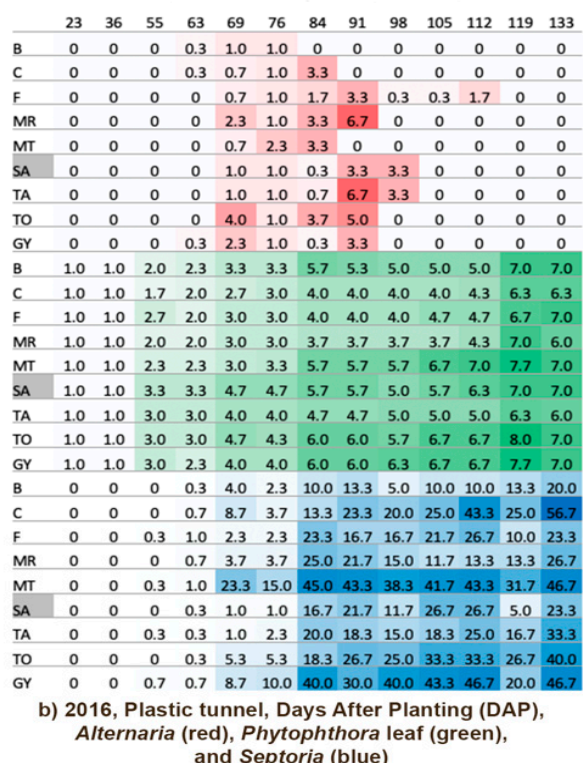

Figure 4. Cont.

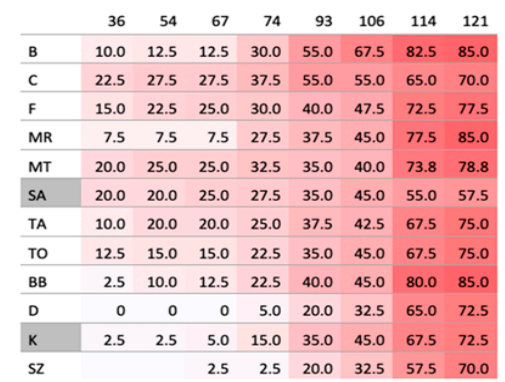

d) 2015, Open-field, Days After Planting (DAP), Alternaria (red)

\begin{tabular}{|c|c|c|c|c|c|c|c|}
\hline & 15 & 26 & 36 & 55 & 63 & 69 & 76 \\
\hline B & 1.0 & 1.0 & 1.0 & 2.3 & 3.3 & 7.5 & 9.0 \\
\hline c & 1.0 & 1.0 & 1.0 & 2.3 & 3.0 & 6.5 & 7.0 \\
\hline$F$ & 1.0 & 1.0 & 1.0 & 2.0 & 3.0 & 6.3 & 7.3 \\
\hline MR & 1.0 & 1.0 & 1.0 & 2.0 & 2.3 & 6.0 & 6.8 \\
\hline MT & 1.0 & 1.0 & 1.0 & 2.0 & 3.8 & 7.0 & 7.5 \\
\hline SA & 1.0 & 1.0 & 1.0 & 2.5 & 3.8 & 7.0 & 7.0 \\
\hline TA & 1.0 & 1.0 & 1.0 & 2.3 & 3.0 & 7.0 & 7.0 \\
\hline To & 1.0 & 1.0 & 1.0 & 2.0 & 3.5 & 7.0 & 7.8 \\
\hline BB & 1.0 & 1.0 & 1.0 & 2.5 & 4.3 & 7.5 & 9.0 \\
\hline D & 1.0 & 1.0 & 1.0 & 2.3 & 4.5 & 8.0 & 9.0 \\
\hline K & 1.0 & 1.0 & 1.0 & 2.3 & 4.3 & 7.3 & 8.3 \\
\hline$S z$ & 1.0 & 1.0 & 1.0 & 2.0 & 3.8 & 6.5 & 7.5 \\
\hline B & 1.0 & 1.0 & 1.0 & 1.0 & 2.0 & 2.5 & 5.8 \\
\hline c & 1.0 & 1.0 & 1.0 & 1.3 & 1.0 & 2.0 & 3.8 \\
\hline$F$ & 1.0 & 1.0 & 1.0 & 1.0 & 1.5 & 2.3 & 3.5 \\
\hline MR & 1.0 & 1.0 & 1.0 & 1.0 & 3 & 2.0 & 3.0 \\
\hline MT & 1.0 & 1.0 & 1.0 & 1.3 & 1.0 & 2.3 & 4.8 \\
\hline SA & 1.0 & 1.0 & 1.0 & 1.5 & 1.0 & 2.0 & 5.0 \\
\hline TA & 1.0 & 1.0 & 1.0 & 1.5 & 1.3 & 2.0 & 3.8 \\
\hline то & 1.0 & 1.0 & 1.0 & 1.0 & 1.5 & 2.8 & 5.8 \\
\hline BB & 1.0 & 1.0 & 1.0 & 1.5 & 2.8 & 4.0 & 4.8 \\
\hline D & 1.0 & 1.0 & 1.0 & 1.0 & 3.5 & 6.3 & 5.3 \\
\hline k & 1.0 & 1.0 & 1.0 & 1.0 & 3.0 & 4.5 & 4.0 \\
\hline Sz & 1.0 & 1.0 & 1.0 & 1.0 & 2.8 & 3.3 & 3.8 \\
\hline
\end{tabular}

e) 2016, Open-field, Days After Planting (DAP), Phytophthora leaf (green), 


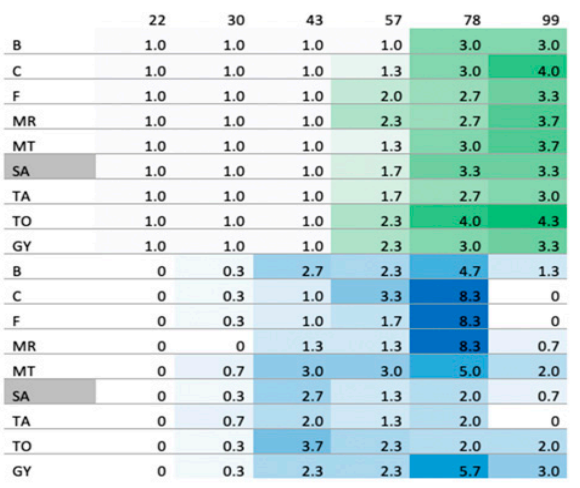

c) 2017, Plastic tunnel, Days After Planting (DAP), Phytophthora leaf (green), and Septoria (blue)

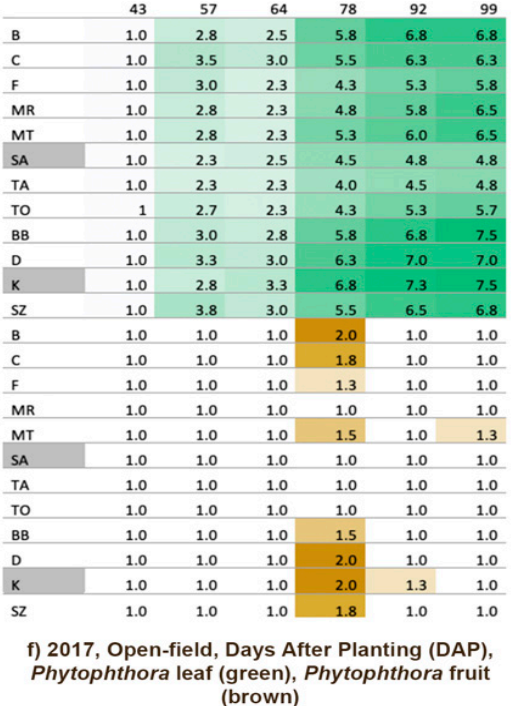

Figure 4. Heat map of Alternaria (red), Phytophthora leaf (green), fruit (brown) and Septoria (blue) infestation average of tomato landraces in 2015 (a,d), 2016 (b,e) and $2017(\mathbf{c}, \mathbf{f})$, in plastic tunnel and on open field respectively. B: 'Balatonboglár'; C: ‘Cegléd'; F: 'Fadd'; GY: ‘Gyöngyös'; MR: 'Máriapócs'; MT: 'Mátrafüred'; TA: 'Tarnaméra'; TO: 'Tolna megye'. The control variety is SA: 'San Marzano'. Determinate gene bank items: BB: ‘Balatonboglár'; D: 'Dány'; SZ: 'Szentlőrinckáta'. The control variety is K: 'Kecskeméti 549'. Control varieties are highlighted with grey background color.

\subsubsection{Plastic Tunnel}

In 2015, measurable damage in the plastic tunnel was caused only by Alternaria solani, and two PCs were extracted. The observed high rate of variance was explained by late infection. There were no significant differences between the tomato accessions and control varieties (Table 8, Figure 4). In 2016, all variables of the Phytophthora infestans leaf infestation were transformed into the same principal component (F1). According to the post hoc test, 'Gyöngyös' was significantly more susceptible compared to 'Cegléd' and 'Máriapócs' (Table 9). Septoria lycopersici was also detected in this year: the early period was highly significantly differentiated by the accessions. In this period, 'Mátrafüred' was more affected by Septoria leaf spot than landraces 'Tolna megye', 'Tarnaméra' and the control variety 'San Marzano' (Figure 4). The accessions and varieties did not differ significantly when Alternaria (F4) and late Septoria (F2) infections were compared. In 2017, Alternaria and Phytophthora infections were detected; however, significant differences were found only in the case of late Phtyophthora leaf infection (F2): 'Tolna megye' proved to be less tolerant than the other gene bank accessions and control varieties. 
Table 8. The results of the principal component analysis for the infection types of the plastic tunnel experiment: the explained variances of the PCs as well as the total explained variance rates; the original variables that are highly correlated with the PCs (with high loadings) and the names that refer to the PCs later on; Wilk's $\lambda$ (unexplained variance rate) values (overall MANOVA results) and the follow-up ANOVA tests (between-subject effects) with F values and their significances.

\begin{tabular}{|c|c|c|c|c|c|c|c|c|}
\hline \multirow{2}{*}{ 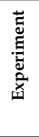 } & \multirow[b]{2}{*}{$\begin{array}{l}\text { Infection Type } \\
\text { Detected }\end{array}$} & \multirow[b]{2}{*}{ Year } & \multicolumn{4}{|c|}{ PCA } & \multicolumn{2}{|c|}{ MANOVA with factor 'Varieties' } \\
\hline & & & $\begin{array}{c}\text { PCA } \\
\text { Total Variance } \\
\text { Explained } \%\end{array}$ & $\begin{array}{c}\text { Principal } \\
\text { Components } \\
\text { (Explained } \\
\text { Variances \%) }\end{array}$ & $\begin{array}{l}\text { Highly Correlated } \\
\text { Explaining } \\
\text { Variables }\end{array}$ & Referred to as & Wilk's $\lambda$ & $\begin{array}{c}\text { Between-Subject } \\
\text { Effects } \\
\text { F(8;18) }\end{array}$ \\
\hline \multirow{9}{*}{ 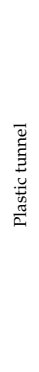 } & \multirow{2}{*}{ Alternaria } & \multirow{2}{*}{2015} & \multirow{2}{*}{$79.91 \%$} & $\mathrm{~F} 1(61.99 \%)$ & A106, A114, A125 & 'Alternaria_2015_late' & \multirow{2}{*}{$0.29 \mathrm{~ns}$} & - \\
\hline & & & & F2(7.92\%) & A67, A79 & 'Alternaria_2015_early' & & - \\
\hline & \multirow{4}{*}{$\begin{array}{c}\text { Alternaria, } \\
\text { Phytophthora_leaf, } \\
\text { Septoria }\end{array}$} & \multirow{4}{*}{2016} & \multirow{4}{*}{$67.64 \%$} & $\mathrm{~F} 1(28.36 \%)$ & PL (all) & 'Phytophthora_leaf_2016' & \multirow{4}{*}{$<0.001 * * *$} & $10.78^{* * *}$ \\
\hline & & & & F2(19.81\%) & $\begin{array}{c}\text { S69, S84, S91, S98, } \\
\text { S105, S112, S119, } \\
\text { S133 }\end{array}$ & 'Septoria_2016_late' & & $1.55^{\mathrm{ns}}$ \\
\hline & & & & $\mathrm{F} 3(11.80 \%)$ & $\mathrm{S} 55, \mathrm{~S} 63, \mathrm{~S} 76, \mathrm{~S} 84$ & 'Septoria_2016_early' & & $4.57 * * *$ \\
\hline & & & & $\mathrm{F} 4(7.67 \%)$ & Alternaria (all) & 'Alternaria_2016' & & $1.19^{\mathrm{ns}}$ \\
\hline & \multirow{3}{*}{$\begin{array}{l}\text { Phytophthora_leaf, } \\
\text { Septoria }\end{array}$} & \multirow{3}{*}{2017} & \multirow{3}{*}{$71.02 \%$} & $\mathrm{~F} 1(31.56 \%)$ & S30, S43, FL57 & 'Alternaria+Phytophthora_leaf_2017_early' & \multirow{3}{*}{$0.07^{* * *}$} & $0.76^{\mathrm{ns}}$ \\
\hline & & & & $\mathrm{F} 2(20.73 \%)$ & PL78, PL92 & 'Phytophthora_leaf_2017_late' & & $6.86^{* * *}$ \\
\hline & & & & F3(18.73\%) & S57, S78 & 'Alternaria_2017_late' & & $2.26^{\mathrm{ns}}$ \\
\hline
\end{tabular}

Follow-up ANOVA with Bonferroni's Type I error correction: ${ }^{* * *}$ significant at $p<0.001$; ${ }^{\text {ns }}$ not significant. Alternaria ('A'), Phytophthora leaf ('PL'), Phytophthora fruit ('PF') and Septoria ('S'); numbers after the names represent the day after planting (DAP). According to between-subject effects, significant PCs are in bold.

Table 9. The post hoc test results of the significant PCs obtained from the infection data of the different tomato landrace gene bank items and control varieties regarding the plastic tunnel experiment. Different letters from lower to higher rate of infection represent significantly different groups (Games-Howell's, $p<0.05$ ). Abbreviations of the Hungarian landrace gene bank items are: B: ‘Balatonboglár'; C: 'Cegléd'; F: ‘Fadd'; GY: ‘Gyöngyös'; MR: ‘Máriapócs'; MT: 'Mátrafüred'; TA: 'Tarnaméra'; TO: 'Tolna megye'. The control variety is SA: 'San Marzano'. Control varieties are highlighted with grey background color.

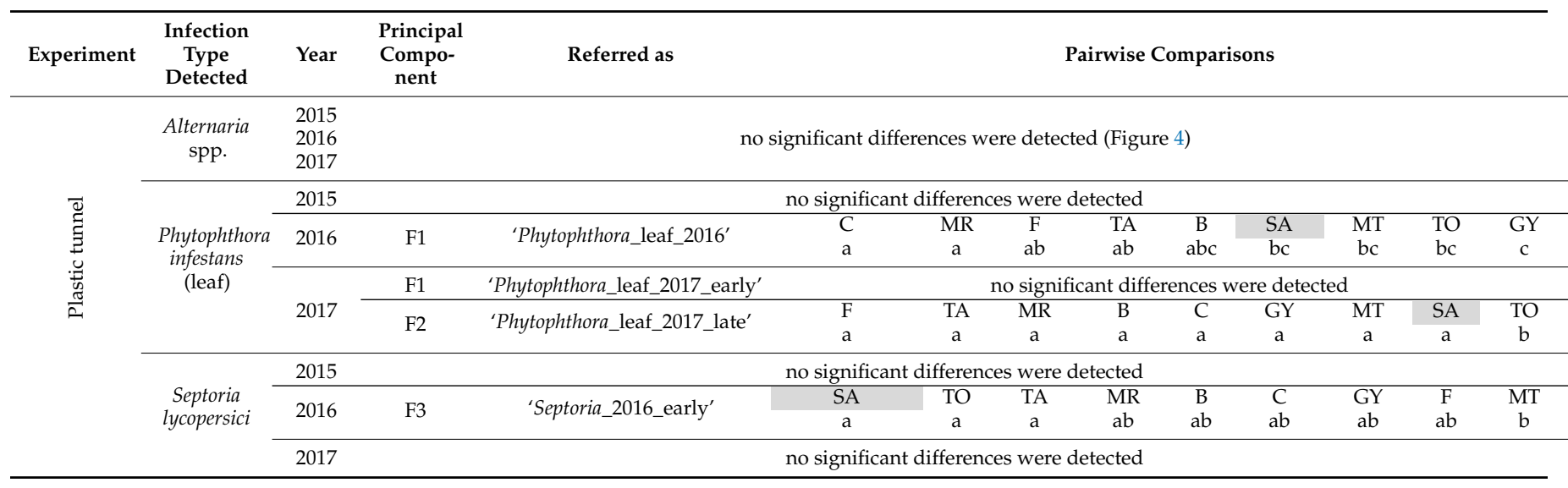

\subsubsection{Open Field}

In 2015, similar to the results of the plastic tunnel experiment, tomato gene bank accessions had different responses to early infestations of Alternaria (Table 10). Determinatetype tomato plants seemed to be less susceptible than some of the indeterminate tomatoes, such as 'Cegléd', 'Fadd', 'Mátrafüred' and the control 'San Marzano' (Table 11, Figure 4). The season in 2016 was shortened by a serious Phytophthora pressure that infected every experimental tomato plant from the beginning of the generative growth phase. Fruit and leaf symptoms of this pathogen were visible as well, affecting determinate types (especially the accession 'Dány'). These plants differed significantly from the other accessions with some overlapping. Several indeterminate tomato accessions, such as 'Máriapócs', 'Cegléd', 'Tarnaméra' and 'Fadd', formed another group, based on their significantly lower infestation levels. In 2017, Phytophthora occurred again, and the data of this year were analyzed by certain DAP days (PCA was not performed). Depending on the DAP, accessions were performed differently, but the tendency was similar to the previous year. 
Table 10. The results of the principal component analysis for the infection types of the open-field experiment: the explained variances of the PCs as well as the total explained variance rates; the original variables that are highly correlated with the PCs (with high loadings) and the names that refer to the PCs later on; Wilk's $\lambda$ (unexplained variance rate) values (overall MANOVA results) and the follow-up ANOVA tests (between-subject effects) with F values and their significances.

\begin{tabular}{|c|c|c|c|c|c|c|c|c|}
\hline \multirow{2}{*}{ 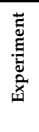 } & \multirow[b]{2}{*}{$\begin{array}{l}\text { Infection Type } \\
\text { Detected }\end{array}$} & \multirow[b]{2}{*}{ Year } & \multicolumn{4}{|c|}{ PCA } & \multicolumn{2}{|c|}{ MANOVA with Factor 'Varieties' } \\
\hline & & & $\begin{array}{c}\text { PCA } \\
\text { Total Variance } \\
\text { Explained \% }\end{array}$ & $\begin{array}{c}\text { Principal } \\
\text { Components } \\
\text { (Explained } \\
\text { Variances \%) }\end{array}$ & $\begin{array}{l}\text { Highly Correlated } \\
\text { Explaining } \\
\text { Variables }\end{array}$ & Referred to as & Wilk's $\lambda$ & $\begin{array}{c}\text { Between-Subject } \\
\text { Effects } \\
\text { F(11;36) }\end{array}$ \\
\hline \multirow{6}{*}{ 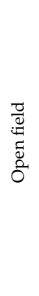 } & \multirow{2}{*}{ Alternaria } & \multirow[t]{2}{*}{2015} & \multirow{2}{*}{$75.45 \%$} & $\mathrm{~F} 1(48.07 \%)$ & $\begin{array}{l}\text { A36, A54, A67, A74, } \\
\text { A93 }\end{array}$ & 'Alternaria_2015_early' & \multirow{2}{*}{$0.20^{* * *}$} & $7.36 * * *$ \\
\hline & & & & $\mathrm{F} 2(27.38 \%)$ & $\begin{array}{l}\text { A93, A106, A114, } \\
\text { A121 }\end{array}$ & 'Alternaria_2015_late' & & $1.78^{\mathrm{ns}}$ \\
\hline & \multirow{2}{*}{$\begin{array}{l}\text { Phytophthora leaf, } \\
\text { Phytophthora_fruit }\end{array}$} & \multirow{2}{*}{2016} & \multirow{2}{*}{$67.64 \%$} & $\mathrm{~F} 1(44.77 \%)$ & $\begin{array}{l}\text { PF63, PF69, PF76, PL } \\
\text { (all except DAP 55) }\end{array}$ & $\begin{array}{c}\text { 'Phytophthora_fruit_and_leaf_2016_ } \\
\text { _exceptDAP55' }\end{array}$ & \multirow{2}{*}{$<0.13^{* * *}$} & $13.97 * * *$ \\
\hline & & & & F2(20.09\%) & PF55, PL55 & $\begin{array}{c}\text { 'Phytophthora_fruit and leaf_ } \\
\text { 2016_DAP55' }\end{array}$ & & $1.49^{\mathrm{ns}}$ \\
\hline & \multirow{2}{*}{ Phytophthora_leaf } & \multirow{2}{*}{2017} & \multirow{2}{*}{\multicolumn{3}{|c|}{$\begin{array}{l}\text { Instead of PCA, MANOVA was performed with the original variables } \\
\text { PL57, PL64, PL78, PL92, PL99 }\end{array}$}} & 'Phytophthora_leaf_2017 exceptDAP64' & \multirow{2}{*}{$0.05 * * *$} & $>3.60^{* * *}$ \\
\hline & & & & & & 'Phytophthora_leaf_2017_DAP64' & & $1.69 \mathrm{~ns}$ \\
\hline
\end{tabular}

Follow-up ANOVA with Bonferroni's Type I error correction: ${ }^{* * *}$ significant at $p<0.001$; ${ }^{\text {ns }}$ not significant. Alternaria ('A'), Phytophthora leaf ('PL'), Phytophthora fruit ('PF') and Septoria ('S'); numbers after the names represent the day after planting (DAP). According to between-subject effects, significant PCs or variables are in bold.

Table 11. The post hoc test results of the significant PCs obtained from the infection data of the different tomato gene bank items and control varieties regarding the open-field experiment. Different letters from lower to higher rate of infection represent significantly different groups (Games-Howell's, $p<0.05$ ). Abbreviations of the indeterminate Hungarian gene bank items are: B: ‘Balatonboglár'; C: 'Cegléd'; F: 'Fadd'; GY: ‘Gyöngyös'; MR: ‘Máriapócs'; MT: 'Mátrafüred'; TA: 'Tarnaméra'; TO: 'Tolna megye'. The control variety is SA: 'San Marzano'. Determinate gene bank items: BB: 'Balatonboglár'; D: 'Dány'; SZ: 'Szentlőrinckáta'. The control variety is K: 'Kecskeméti 549'. Control varieties are highlighted with grey background color.

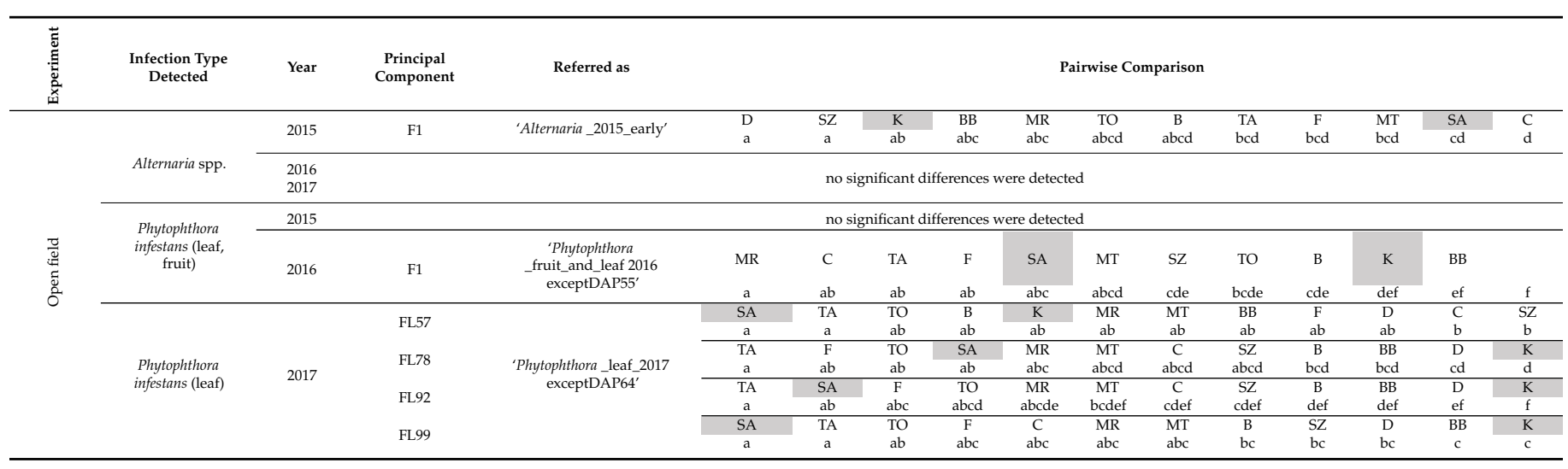

DAP: day after planting.

\subsection{Subjective Observations}

\subsubsection{Yield and Fruit Quality}

The above analyzed parameter investigations were supplemented with non-quantified observations of the studied tomato plants, as yield and disease can be influenced by additional symptoms and factors. Regarding yield-related observations, fruit parameters, 'San Marzano' and 'Tarnaméra' were susceptible to blossom-end rot. A. solani symptoms appeared mainly as secondary symptoms on fruit injuries (e.g., cracking, sun scald and blossom-end rot). Although 'Fadd', 'Tolna megye' and 'Mátrafüred' produced high yields, the occurrence of green shoulder, cat-facing and fruit cracking resulted in a high amount of non-marketable fruit (Table 12). Harvesting 'Máriapócs', a cherry tomato type, is difficult, because the pedicel is strongly attached, and the fruit can crack right at the moment of picking. In the case of 'Mátrafüred', 'Tolna megye' and 'Gyöngyös', flower abscission occurred frequently. Fruit of 'Tarnaméra' and 'San Marzano' were so similar that it was difficult to distinguish them without their labels. 
Table 12. Highlighted subjective observations regarding indeterminate tomato landraces and control varieties experienced on both experimental locations.

\begin{tabular}{|c|c|c|c|c|}
\hline $\begin{array}{c}\text { Landrace/Control } \\
\text { Variety Name }\end{array}$ & $\begin{array}{c}\text { Fruit } \\
\text { Physiological } \\
\text { Disorders }\end{array}$ & Foliage Density & $\begin{array}{l}\text { Handling of } \\
\text { Vegetative } \\
\text { Growth }\end{array}$ & Harvesting \\
\hline 'Cegléd' & cracking & intermediate & easy & easy \\
\hline 'Fadd' & $\begin{array}{l}\text { cracking, green } \\
\text { shoulder }\end{array}$ & intermediate & easy & moderate \\
\hline 'Gyöngyös' & cracking & sparse & difficult & easy \\
\hline 'Máriapócs' & $\begin{array}{l}\text { cracking } \\
\text { cracking, green }\end{array}$ & intermediate & moderate & difficult \\
\hline 'Mátrafüred' & $\begin{array}{l}\text { shoulder, flower } \\
\text { abortion }\end{array}$ & sparse & difficult & moderate \\
\hline 'Tarnaméra' & blossom end rot & dense & easy & moderate \\
\hline ‘Tolna megye' & $\begin{array}{l}\text { catface, flower } \\
\text { abortion }\end{array}$ & sparse & difficult & moderate \\
\hline $\begin{array}{l}\text { 'San Marzano' } \\
\text { (control) }\end{array}$ & blossom end rot & dense & easy & moderate \\
\hline
\end{tabular}

\subsubsection{Vegetative Characteristics}

'Fadd', 'Tarnaméra' and 'San Marzano' had compact foliage with strong, thick shoots and leaves. 'Mátrafüred' and 'Tolna megye' had the weakest growth, lower leaf density and low intensity of sucker sprouting. As we did not use pruning scissors in order to prevent transporting bacteria and viruses from plant to plant, tying the stem to the support system and taking off suckers by hand during maintenance (handling of vegetative growth) was difficult in the case of 'Mátrafüred', 'Tolna megye' and 'Gyöngyös', due to the low angle of leaves, and the weak stem. Though only indeterminate tomatoes are discussed in this section, one trait of a determinate tomato accession was remarkable as well: 'Szentlőrinckáta' showed more intensive shoot sprouting, which supported the plant to recover even after a severe P. infestans infection.

\section{Discussion}

This publication is the first report on the disease tolerance of Hungarian tomato landraces, and the first yield data about 'Balatonboglár', 'Fadd', 'Mátrafüred', 'Tarnaméra' and 'Tolna megye' indeterminate accessions. The aim of this study was to test whether these landrace accessions:

(1) Constitute a viable option for tomato assortment diversification even under current environmental and climatic conditions;

(2) Have sufficient resistance against plant diseases;

(3) Can thus substitute commercial varieties under organic farming conditions, even if they are cultivated outside of their place of origin.

For this purpose, yield and disease tolerance, two of the top priorities of the agronomic traits of tomato varieties according to farmer surveys [44] provide the most important indicators.

Different types of tomato gene bank accessions were compared in the experiment. According to Tembe et al. [10], the yield depends on the tomato growing type and fruit weight. Accordingly, in the plastic tunnel, accessions with a larger fruit size ('Tolna megye', 'Mátrafüred' and 'Gyöngyös') gave higher yields. The yields of indeterminate varieties vigorously improved in the plastic tunnel. On the open field, with the given environmental circumstances and management techniques, determinate landraces performed better than indeterminate varieties, which is in agreement with earlier studies $[45,46]$. Concerning the good performance of determinate varieties, some agrotechnical elements, usually applied for determinate tomatoes, may be considered in the case of indeterminate accessions as well, such as less pruning $[47,48]$, reduced irrigation and rainfed environment $[19,49]$, in order to improve their fruit quality and yield on the open field. Differences among landraces were visible along the fruit ripening timeline. The determinate, late-season 'Szentlőrinckáta' with its high yield was outstanding under open-field conditions (provided that no Phytophthora 
infestans infection or frost occurs in the autumn). Farmers are recommended to select tomato varieties after considering their ripening time, and time their introduction to the market accordingly. The performances of landraces and control varieties were different according to the season as well. 'Tolna megye', 'Mátrafüred' and 'Cegléd' ensured higher yields early in the season in both management systems, while in the plastic tunnel, 'Tolna megye', 'Fadd' and 'Gyöngyös' yields were high later on in the season. Determinate accessions had as high late yield as expected on the open field. The cherry-type 'Máriapócs' always had a low yield; nevertheless, it is recommended to grow as it is tasteful, diversifies the assortment and its ripening timeline is the longest if suckers with clusters are not removed. These results suggest that with the right timing, landraces can perform similarly or even better than commercial varieties, in concordance with other studies $[19,50]$. Although the different experimental design and environmental parameters do not allow us to analyze the results of the plastic tunnel and open field together, it was shown that outcomes for both methods are similar with some key differences, e.g., the potential yield of indeterminate tomato gene bank accessions can be higher under protected management.

Regarding climate, there were three different years with different relative humidity and temperature conditions that may have promoted or prohibited the occurrence of diseases. According to Sharma and Ahir [51], the maximum mycelial growth of Alternaria alternata was observed at $25^{\circ} \mathrm{C}$ in vitro, but its growth decreased at $30^{\circ} \mathrm{C}$, which explains the lower infection rate in 2015 in the warm plastic tunnel, compared to the open-field observations. However, under the same climate conditions, determinate tomatoes proved to be less susceptible. To judge the severity of plant pathogens is a complex objective. Septoria lycopersici, the leafspot disease, does not have a direct effect on fruit marketability, but it can contribute to yield loss [52,53]. This pathogen caused severe damage in the plastic tunnel with high humidity. Similarly, rainy, humid weather may induce a severe $P$. infestans infection, causing serious damage to an open-field organic tomato, and if foliage is infected before fruit ripening, even a complete yield loss may occur, as it was found in the case of determinate tomato types in 2016. The severity of infection depends on the current weather, as well as on the season and the applied management system in general. During the three-year experiment, we had the opportunity to monitor these plant pathogens, which are the three most important diseases according to a survey among organic farmers [44]. The foliage of 'Gyöngyös', 'Tolna megye' and the control 'San Marzano' proved to be more susceptible to $P$. infestans in the plastic tunnel than on the open field. Leaf symptom rates on 'Cegléd', 'Fadd' and 'Máriapócs' were less severe in all years and locations. The open-field determinate accessions were more exposed to soil-borne $P$. infestans due to their compact foliage located close to the ground. To Alternaria solani, however, two of the determinate tomatoes, 'Dány' and 'Szentlőrinckáta', were less susceptible than indeterminate plants.

Subjective observations also influence the choice among accessions. Tomato landraces with diverse colors and flavors are popular among consumers, and this fact motivates farmers to maintain landrace populations. Conversations with farmers about maintenance also revealed that certain attributes of the tomato plant, including growth habits, can make maintenance, such as phytotechnical works, difficult. 'San Marzano' and 'Tarnaméra' with their compact habits may induce the occurrence of pests and pathogens, but given their lower vegetative mass compared to other accessions, they were found to be less susceptible to diseases. An initial infection may cause more serious damage and a higher rate of non-marketable yield in the case of accessions that bear heavier fruits in a low number ('Tolna megye' and 'Mátrafüred'). These results suggest that tomato plants with similar consumption types, fruit sizes and growth habits showed similar yield results and levels of disease infection. If the farmer aims for an early yield, 'Tolna megye', 'Mátrafüred' and 'Cegléd' are recommended. Additionally, the yield and disease tolerance of landraces may be enhanced with proper agricultural techniques, and applying the appropriate growing type (determinate or indeterminate) tomato for open-field or greenhouse production. 


\section{Conclusions}

The presented study suggests that the differences in the susceptibilities of the tested tomato landraces to major diseases are rather small. The yield and disease parameters of the landrace accessions and control varieties varied in the early and late seasons, occasionally within one year; therefore, it was concluded that there are no significant differences between the studied landraces and the control varieties, which means that growing landraces does not constitute a higher risk for organic farmers than growing the tested popular commercial cultivars. This revealed that certain accessions can be highly recommended. Many of the studied tomato landraces are recommended for fresh consumption, as they are suitable options with a high yield and lower susceptibility towards Phytophthora infestans, especially when grown in a plastic tunnel. Similarly, the studied processing types of landraces are also recommended with the careful selection of their environment and management techniques, considering their sensitivity against $P$. infestans. On the open field, all three determinate accessions are recommended with reliably high yields, taking into account that an openfield environment may present a higher risk of $P$. infestans infection. Tomato landraces are maintained in gene banks ex situ; however, they can still perform well under the current environmental, on-farm conditions, compared to commercial varieties. Agronomic, morphological or nutrient traits of tomato landraces may present valuable material for future breeding; moreover, their special gastronomic and local historical values make landraces popular, even if they are not cultivated at their place of origin.

Author Contributions: Conceptualization, D.R., L.C., D.D. and F.T.; methodology, D.R., M.L. and F.T.; software, M.L.; validation, M.L., K.B.-P. and F.T.; formal analysis, M.L.; investigation, D.R., F.T. and K.B.-P.; resources, D.D.; data curation, K.B.-P., D.R. and L.C.; writing—original draft preparation, K.B.P., D.R. and M.L. writing-review and editing, K.B.-P., L.C., M.L.,D.D., F.T.B. and F.T.; visualization, K.B.-P., M.L., L.C. and F.T.; supervision, L.C., M.L. and F.T.; project administration, D.D.; funding acquisition, D.D. All authors have read and agreed to the published version of the manuscript.

Funding: This research was financially supported by the Hungarian Research Institute of Organic Agriculture (ÖMKI, Hungary) and the 'Sárközy Péter Foundation for Bioculture'. This study was also supported by the Ministry for Innovation and Technology within the framework of the Higher Education Institutional Excellence Program (TKP2020-IKA-12) of the Hungarian University of Agriculture and Life Sciences.

Institutional Review Board Statement: Not applicable.

Informed Consent Statement: Not applicable.

Data Availability Statement: Not applicable.

Acknowledgments: The authors are grateful for the farmers, Daniella Vukovics and Áron Pető for their collaboration and providing their land for this on-farm trial, and colleagues, Katalin Mali, Máté Makra, Anna Vajnai, Szabolcs Grózinger, Rozália Tóth, Anikó Fehér and Tina Kovács for assisting in the maintenance and data collection. We would like to thank Barbara Cseperkálóné-Mirek, Fruzsina Gyöngy and the personnel at the Experimental and Research Field of the Department of Ecological and Sustainable Production Systems at the former Szent István University for providing us with the necessary tomato seedlings each year.

Conflicts of Interest: The authors declare no conflict of interest.

\section{References}

1. Bergougnoux, V. The history of tomato: From domestication to biopharming. Biotech. Adv. 2014, 32, 170-189. [CrossRef] [PubMed]

2. FAOSTAT. 2019. Available online: http:/ /www.fao.org/faostat/en/\#data/QC (accessed on 10 March 2021).

3. Yi, S.S.; Jatoi, S.A.; Fujimura, T.; Yamanaka, S.; Watanabe, J.; Watanabe, K.N. Potential loss of unique genetic diversity in tomato landraces by genetic colonization of modern cultivars at a non-center of origin. Plant Breed. 2008, 127, 189-196. [CrossRef]

4. Mäder, P.; Fliessbach, A.; Dubois, D.; Gunst, L.; Fried, P.; Niggli, U. Soil fertility and biodiversity in organic farming. Science 2002, 296, 1694-1697. [CrossRef] [PubMed]

5. Østergård, H.; Finckh, M.R.; Fontaine, L.; Goldringer, I.; Hoad, S.P.; Kristensen, K.; Lammerts van Bueren, E.T.; Mascher, F.; Munki, L.; Wolfe, M.S. Time for a shift in crop production: Embracing complexity through diversity at all levels. J. Sci. Food Agric. 2009, 89, 1439-1445. [CrossRef] 
6. Willer, H.; Lernoud, J. The World of Organic Agriculture Statistics and Emerging Trends; FiBL-IFOAM Report; Research Institute of Organic Agriculture (FiBL) Frick, and IFOAM—Organics International: Bonn, Germany, 2015; pp. 1-333.

7. Lammerts van Bueren, E.T.; Struik, P.C.; Jacobsen, E. Ecological concepts in organic farming and their consequences for an organic crop ideotype. Neth. J. Agric. Sci. 2002, 50, 1-26. [CrossRef]

8. Murphy, K.M.; Campbell, K.G.; Lyon, S.R.; Jones, S.S. Evidence of varietal adaptation to organic farming systems. Field Crops Res. 2007, 102, 172-177. [CrossRef]

9. Wolfe, M.S.; Baresel, J.P.; Desclaux, D.; Goldringer, I.; Hoad, S.; Kovacs, G.; Löschenberger, F.; Miedaner, T.; Østergård, H.; Lammerts van Bueren, E.T. Developments in breeding cereals for organic agriculture. Euphytica 2008, 163, 323-346. [CrossRef]

10. Tembe, K.O.; Chemining, G.; Ambuko, J. Evaluation of African tomato landraces (Solanum lycopersicum) based on morphological and horticultural traits. Agric. Nat. Resour. 2018, 52, 536-542. [CrossRef]

11. Lammerts van Bueren, E.T.; Jonesc, S.S.; Tammd, L.; Murphy, K.M.; Myerse, J.R.; Leifertf, C.; Messmerd, M.M. The need to breed crop varieties suitable for organic farming, using wheat, tomato and broccoli as examples: A review. J. Life Sci. 2011, 58, 193-205. [CrossRef]

12. Camacho Villa, T.C.; Maxted, N.; Scholten, M.; Ford-Lloyd, B. Defining and identifying crop landraces. Plant Genet. Resour. 2005, 3, 373-384. [CrossRef]

13. Harlan, J.R. Our vanishing genetic resources. Science 1975, 188, 618-621. [CrossRef]

14. Hawkes, J.G. The Diversity of Crop Plants; Harvard University Press: Cambridge, MA, USA, 2013; p. 102. [CrossRef]

15. Gupta, C.; Salgotra, R.K.; Mahajan, G. Future threats and opportunities facing crop wild relatives and landrace diversity. In Rediscovery of Genetic and Genomic Resources for Future Food Security; Springer: Singapore, 2020; pp. 351-364. [CrossRef]

16. Perrino, E.V.; Perrino, P. Crop wild relatives: Know how past and present to improve future research, conservation and utilization strategies, especially in Italy: A review. Resour. Crop Evol. 2020, 67, 1067-1105. [CrossRef]

17. Harlan, J.R.; de Wet, J.M.J. Towards a rational classification of cultivated plants. Taxon 1971, 20, 509-517. [CrossRef]

18. Perrino, E.V.; Wagensommer, R.P. Crop wild relatives (CWR) priority in Italy: Distribution, ecology, in situ and ex situ conservation and expected actions. Sustainability 2021, 13, 1682. [CrossRef]

19. Fullana-Pericàs, M.; Conesa, M.; Douthe, C.; El Aou-ouad, H.; Ribas-Carbó, M.; Galmés, J. Tomato landraces as a source to minimize yield losses and improve fruit quality under water deficit conditions. Agric. Water Manag. 2019, 223, 105722. [CrossRef]

20. Tieman, D.; Zhu, G.; Resende, M.F.R.; Lin, T.; Nguyen, C.; Bies, D.; Rambla, J.L.; Beltran, K.S.O.; Taylor, M.; Zhang, B.; et al. A chemical genetic roadmap to improved tomato flavor. Science 2017, 355, 391-394. [CrossRef]

21. Akino, S.; Takemoto, D.; Hosaka, K. Phytophthora infestans: A review of past and current studies on potato late blight. J. Gen. Plant Pathol. 2014, 80, 24-37. [CrossRef]

22. Chaerani, R.; Voorrips, R.E. Tomato early blight (Alternaria solani): The pathogen, genetics, and breeding for resistance. J. Gen. Plant Pathol. Pathol. 2006, 72, 335-347. [CrossRef]

23. Fry, W.E. Late Blight of Potatoes and Tomatoes; Fact Sheet 726.20, Vegetable Crops, Integrated Pest Management; New York State IPM Program, Cornell University: New York, NY, USA, 1998.

24. Fry, W. Phytophthora infestans: The plant (and R gene) destroyer. Mol. Plant. Pathol. 2008, 9, 385-402. [CrossRef]

25. Grigolli, J.F.J.; Kubota, M.M.; Alves, D.P.; Rodrigues, G.B.; Cardoso, C.R.; Henriques da Silva, D.J.; Mizubuti, E.S.G. Characterization of tomato accessions for resistance to early blight. Crop Breed. Appl. Biotechnol. 2011, 11, 174-180. [CrossRef]

26. Jones, J.B.; Jones, J.P.; Stall, R.E.; Zitter, T.A. Compendium of Tomato Diseases; American Phytopathological Society: St. Paul, MN, USA, 1991; p. 73.

27. Nowicki, M.; Foolad, M.R.; Nowakowska, M.; Kozik, E.U. Potato and tomato late blight caused by Phytophthora infestans: An overview of pathology and resistance breeding. Plant Dis. 2012, 96, 4-17. [CrossRef]

28. Nowicki, M.; Kozik, E.U.; Foolad, M.R. Late blight of tomato. In Translational Genomics for Crop Breeding; Varshney, R.K., Tuberosa, R., Eds.; John Wiley \& Sons Ltd.: Hoboken, NJ, USA, 2013; pp. 241-265.

29. Poysa, V.; Brammallz, R.A.; Pitblados, R.E. Effects of foliar fungicide sprays on disease and yield of processing tomatoes in Ontario. Can. J. Plant Sci. 1993, 73, 1209-1215. [CrossRef]

30. Peralta, I.E.; Knap, S.; Spooner, D.M. New species of wild tomatoes (Solanum section Lycopersicon: Solanaceae) from northern Peru. Syst. Bot. 2005, 30, 424-434. [CrossRef]

31. Sanoubar, R.; Barbanti, L. Fungal diseases on tomato plant under greenhouse condition. Eur. J. Biol. Res. 2017, 7, $299-308$.

32. Madden, L.V. Measuring and modeling crop losses at the field level. Phytopathology 1983, 73, 1591-1596. [CrossRef]

33. Monteiro1, F.P.; Ogoshi, C.; Maindra, L.C.; Becker, W.F. Culture medium based on tomato leaves for abundant production of conidia from Septoria lycopersici. Asian J. Agric. Res. 2018, 3, 1-6. [CrossRef]

34. Acciarri, N.; Sabatini, E.; Ciriaci, T.; Rotino, L.G.; Valentino, D.; Tamietti, G. The presence of genes for resistance against Verticillium dahliae in Italian tomato landraces. Eur. J. Hortic. Sci. 2010, 75, 8-14.

35. Salim, A.P.; Saminaidu, K.; Marimuthu, M.; Perumal, Y.; Rethinasamy, V.; Palanisami, J.R.; Vadivel, K. Defense responses in tomato landrace and wild genotypes to early blight pathogen Alternaria solani infection and accumulation of pathogenesis-related proteins. Arch. Phytopathol. Plant Prot. 2011, 44, 1147-1164. [CrossRef]

36. Rogers, M.A.; Wszelaki, A.L. Influence of high tunnel production and planting date on yield, growth, and early blight development on organically grown heirloom and hybrid tomato. HortTechnology 2012, 22, 452-462. [CrossRef] 
37. Panthee, D.R.; Gardner, R.G. "Mountain Merit": A late blight-resistant large-fruited tomato hybrid. HortScience 2010, 45, 1547-1548. [CrossRef]

38. Seidl Johnson, A.C.; Jordan, S.A.; Gevens, A.J. Novel resistance in heirloom tomatoes and effectiveness of resistance in hybrids to Phytophthora infestans US-22, US-23, and US-24 clonal lineages. Plant Dis. 2014, 98, 761-765. [CrossRef]

39. Cseperkálóné-Mirek, B.; Reiter, D.; Divéky-Ertsey, A.; Drexler, D. On-farm assessment of landrace of tomato (Lycopersicon esculentum L.) under organic conditions in Hungary. Acta Fytotechn. Zootechn. 2015, 18, 134-137. [CrossRef]

40. Csambalik, L. Paradicsom Tájfajták Szerepe az Ökológiai Gazdálkodásban (The Role of Tomato Landraces in Organic Farming, in Hungarian). Ph.D. Thesis, Hungarian University of Agriculture and Life Sciences (formerly Szent István University), Budapest, Hungary, 2016; p. 199.

41. Csambalik, L.; Divéky-Ertsey, A.; Pusztai, P.; Boros, F.; Orbán, C.; Kovács, S.; Gere, A.; Sipos, L. Multi-perspective evaluation of phytonutrients-Case study on tomato landraces for fresh consumption. J. Funct. Foods 2017, 33, 211-216. [CrossRef]

42. Csambalik, L.; Gál, I.; Sipos, L.; Gere, A.; Koren, D.; Bíró, B.; Divéky-Ertsey, A. Evaluation of processing type tomato plant genetic resources (Solanum lycopersicum L.) for their nutritional properties in different environments. Plant Genet. Resour. 2019, 17, 488-498. [CrossRef]

43. Horneburg, B.; Becker, H.C. Selection for Phytophthora field resistance in the F2 generation of organic outdoor tomatoes. Euphytica 2011, 180, 357-367. [CrossRef]

44. Hoagland, L.; Navazio, J.; Zystro, J.; Kaplan, I.; Vargas, J.G.; Gibson, K. Key traits and promising germplasm for an organic participatory tomato breeding program in the U.S. HortScience 2015, 50, 1301-1308. [CrossRef]

45. Healy, G.K.; Emerson, B.J.; Dawson, J.C. Tomato variety trials for productivity and quality in organic hoop house versus open field management. Renew. Agric. Food. Syst. 2017, 32, 562-572. [CrossRef]

46. Powell, M.; Gundersen, B.; Cowan, J.; Miles, C.A.; Inglis, D.A. The effect of open-ended high tunnels in western Washington on late blight and physiological leaf roll among five tomato cultivars. Plant Dis. 2014, 98, 1639-1647. [CrossRef]

47. Ara, N.; Bashar, M.K.; Begum, S.; Kakon, S.S. Effect of spacing and stem pruning on the growth and yield of tomato. International. J. Sustain. Crop Prod. 2007, 2, 35-39.

48. Kanyomeka, L.; Shivute, B. Influence of pruning on tomato production under controlled environments. Agric. Trop. Subtrop. 2005, 38, 79-83.

49. Conesa, M.; Fullana-Pericàs, M.; Granell, A.; Galmés, J. Mediterranean long shelf-life landraces: An untapped genetic resource for tomato improvement. Front. Plant Sci. 2020, 10, 1-21. [CrossRef] [PubMed]

50. Guida, G.; Houssemeddine, M.; Mistretta, C.; Oliva, M.; Buonomo, R.; Mascellis, R.D.; Patanè, C.; Rouphael, Y.; Albrizio, R.; Giorio, P. Agronomical, physiological and fruit quality responses of two Italian long-storage tomato landraces under rain-fed and full irrigation conditions. Agric. Water Manag. 2017, 180, 126-135. [CrossRef]

51. Sharma, R.L.; Ahir, R.R. Physiological studies of Alternaria causing Alternaria blight of tomato. J. Entomol. Zool. Stud. 2018, 6, 844-847.

52. Gul, Z.; Ahmed, M.; Ullah-Khan, Z.; Khan, B.; Iqbal, M. Evaluation of tomato lines against septoria leaf spot under field conditions and its effect on fruit yield. Agric. Sci. 2016, 7, 181-186. [CrossRef]

53. Joslin, K.; Taber, H.; Helland, S.; Gleason, M. Control of the foliar disease, Septoria lycopersici, in organic tomato production. HortScience 2019, 39, 831. [CrossRef] 